\title{
LATVIJAS
}

\section{UNIVERSTTATE :}

N IVVERSITY OF: L A I VIA

\section{Geodrinamics \\ and Geospatial \\ Researa \\ CONFERENGE PAPERS}

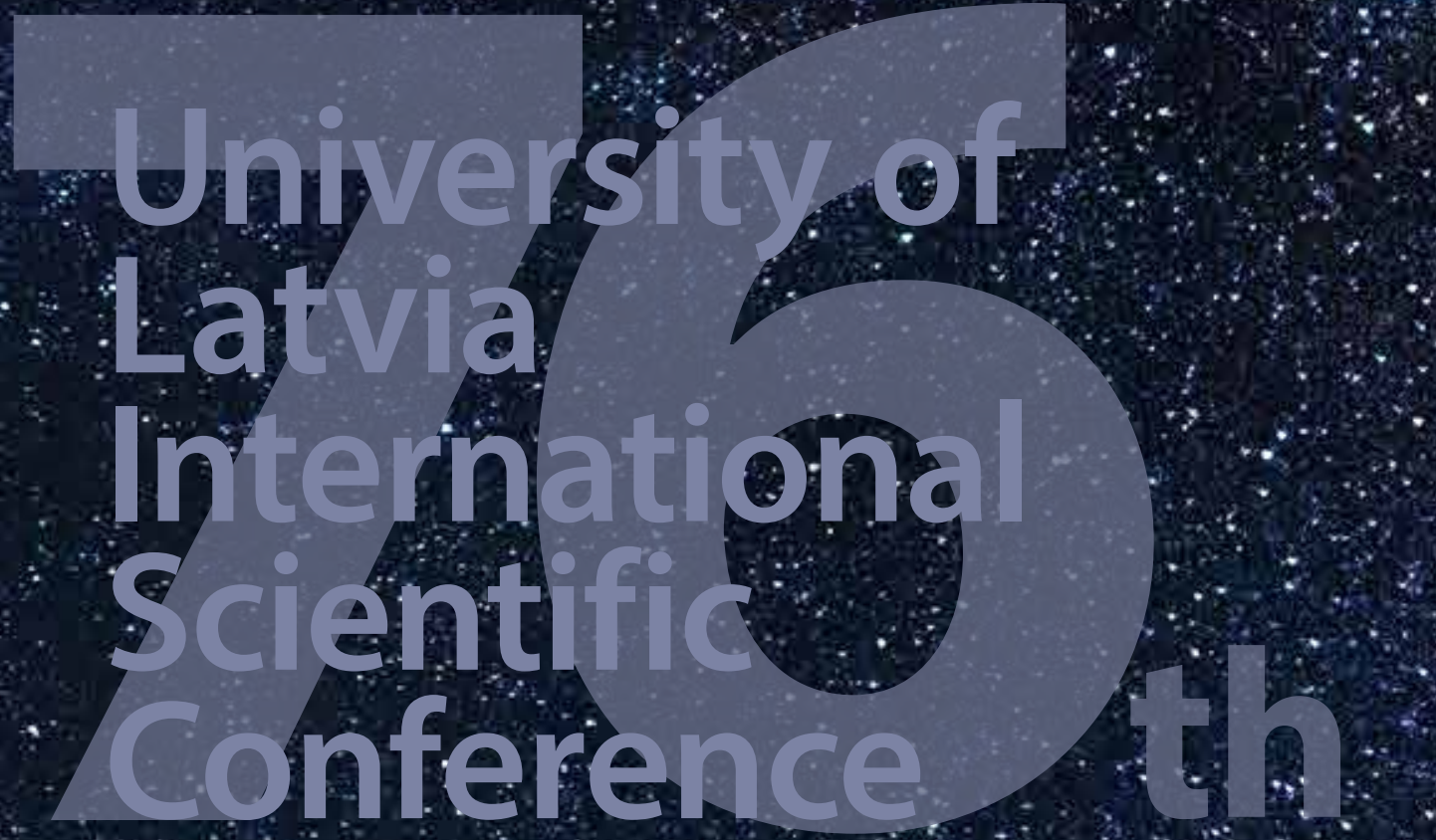


With support of:

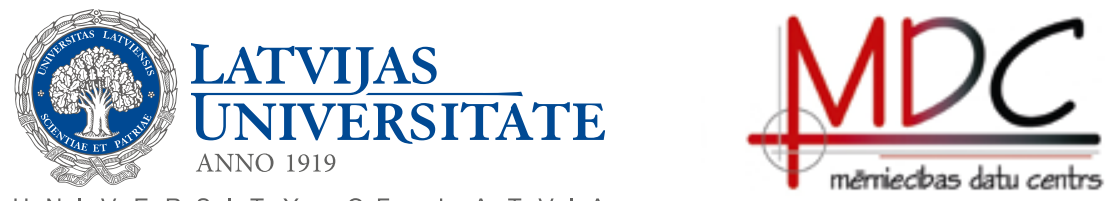

U N I VERS I T Y OF L A T V I A
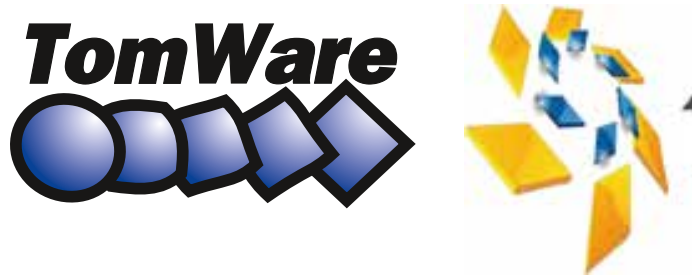
Latvijas Universitātes 76. starptautiskā zinātniskā konference Latvijas Universitātes G̣eodēzijas un G̣eoinformātikas institūts Valsts pētijumu programma RESPROD

University of Latvia $76^{\text {th }}$ International Scientific Conference Institute of Geodesy and Geoinformatics

\section{GEODINAMIKA UN G̦EOKOSMISKIE PËTİJUMI}

\section{GEODYNAMICS AND GEOSPATIAL RESEARCH}

KONFERENCES ZINĀTNISKIE RAKSTI

CONFERENCE PAPERS 
University of Latvia $76^{\text {th }}$ International Scientific Conference. Geodynamics and Geospatial Research. Conference Papers. Riga, University of Latvia, 2018, 62 p.

The conference "Geodynamics and Geospatial Research" organized by the University of Latvia Institute of Geodesy and Geoinformatics of the University of Latvia addresses a wide range of scientific studies and is focused on the interdisciplinarity, versatility and possibilities of research in this wider context in the future to reach more significant discoveries, including business applications and innovations in solutions for commercial enterprises. The research presented at the conference is at different stages of its development and presents the achievements and the intended future. The publication is intended for researchers, students and research social partners as a source of current information and an invitation to join and support these studies.

Published according to the decision No 6 from May 252018 of the University of Latvia Scientific Council

Editor in Chief: prof. Valdis Seglins

Reviewers: $\quad$ Dr. R. Jäger, Karlsruhe University of Applied Sciences

Dr. B. Bayram, Yildiz Technical University

Dr. A. Kluga, Riga Technical university

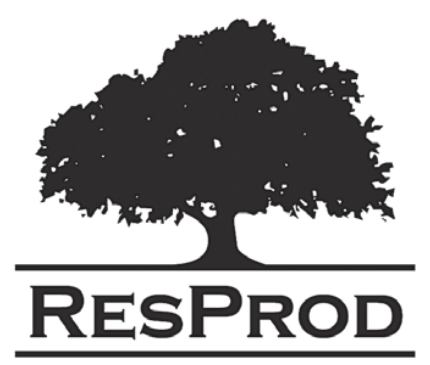

Conference papers are published by support of University of Latvia and State Research program "Forest and Mineral resources studies and sustainable use - new products and Technologies" RESPROD no. 2014.10-4/VPP-6/4 1 project GEO.

Technical editor: Andra Damberga

Computer graphics and design: Ieva Tiltina 


\section{PREFACE}

The Institute of Geodesy and Geoinformatics (GGI) of the University of Latvia are hard working since the reestablishment of the Institute of Geodesy in 1994. The researchers of the Institute of Geodesy (1924-1944) concentrated on the research and education in many advanced topics of that time - development and adjustment of National Geodetic networks, photogrammetry, studies of vertical Earth movement and research in gravimetric and magnetic measurements. Currently the research areas are developed in satellite geodesy and geoinformatics. In this context the main topic of GGI activities is concentrated on development of satellite laser ranging systems (SLR), both the hardware and control software, two SLR prototypes were developed until 2010 and the third most improved model is under development.

The prototype digital zenith camera for studies of vertical deflection has been developed recently. The test results reach precision of 0.1 arc second which is very promising for the improvement of the quality of the National model of Latvia gravity field modeling. The recent version of the National gravity field developed at the GGI has achieved precision of about $2 \mathrm{~cm}$ which is much higher than previous model $(7-8 \mathrm{~cm})$ used in Latvia. The high precision gravity field model is very important for practice. This reaches correspondingly high precision of normal height determination using Global Navigation Satellite systems (GNSS) in geodetic measurements. This support studies of vertical and horizontal motion of the Earth in Latvia by carrying out the analysis of the 7 year GNSS observations at the LatPos and EUPOS-RIGA permanent station networks. These studies provide high quality data for GIS data base development and for digital terrain models Latvia in general and particular cities of Latvia.

The Institute of Geodesy and Geoinformation is substantial research and development unit of the University of Latvia. The Institutes research activities are organized in two departments- Department of Geodesy and Department of Geoinformation. Within the Department of Geodesy the major topics of the activities are concentrated on construction of Satellite laser ranging systems (hardware, software), GNSS applications and substantial for developments is participation in the project EUPOS ${ }^{\circ}$. Department of Geoinformation is developing $2 \mathrm{D}$ and $3 \mathrm{D}$ country-wide geographical databases, large urban geographical databases and DEM, and developing highly detailed local geographical databases. Besides the Department of Geodesy has experienced staff dealing with satellite on ground observations; the hardware and software has been designed for this purpose. Currently several projects are being carried out on the issues of research and development. 
The GGI Institute's research is well-known in the professional field in the world, but in Latvia it is an institution that unites and involves leading researchers from all over the country, regardless of their primal work and has become a sort of informal coordinating center for research in this field. This is also confirmed by the organizing committee of the $76^{\text {th }}$ International Scientific Conference of the University of Latvia, section "Geodynamics and Geospatial Research". The conference was very successful and the results of 22 presented studies, which cover all the main directions of the research carried out in the country, confirm this. Just like more than a hundred specialists from a large number of countries who came to hear particularly the reports from this section of the conference. Especially noteworthy is the very wide representation of the institutions and the repeated gratitude to everyone who participated and supported the conference. The high scientific quality and applied nature of many studies should be highlighted, which will allow to use in the economy this knowledge and numerous scientific solutions already in the next few years, including site development planning and use of the entrails of the Earth.

Professor Dr. geol. Valdis Segliņ̌ February $23^{\text {rd }}, 2018$. 


\section{CONTENT}

PREFACE

Akpinar B.

DEVELOPMENT OF NATIONAL MEASUREMENT SYSTEM

FOR STRUCTURAL HEALTH MONITORING

Balodis J., Vārna I., Haritonova D., Normand M., Jumare I.

ANALYSIS OF CORS POSITIONING RESULTS FOR IMPROVEMENT

OF GNSS/LEVELLING POINT ELLIPSOIDAL HEIGHT ACCURACY .....

Barga I.

SATELLITE IMAGERY FOR OPERATIONAL ACQUIRING AND

ANALYSIS OF FOREST INFORMATION, AND PLANNING OF

SUSTAINABLE ACTIVITIES IN VAST FOREST AREAS

Bayram B.

3D SHORELINE EXTRACTION FROM DIFFERENT TYPES

OF SPATIAL DATA: A CASE STUDY OF TERKOS-ISTANBUL

Cekule M., Čabs K., Mitrofanovs I., Balodis K.

AUTOMATED SURVEYING OF TIMBER ASSORTMENT VOLUMES ....

Eglītis I., Ābele M., Eglītis R., Eglīte V.

BALDONE SCHMIDT TELESCOPE FUTURE PROSPECTS

Gorokhova L., Akter N., Jäger R., Messmer E.

MODEL- AND SENSOR-INTEGRATION FOR

AN INTEGRATED 3D GEOMONITORING IN A MODERN

DATA COMMUNICATION STRUCTURE WITH APPLICATIONS

TO THE STUTTGART TV TOWER

Jäger R., Diekert J., Janugade S., Almagboul M.

GEODETIC CHALLENGES ON POSITIONING \& NAVIGATION

FOR MOBILE GIS PRESENTED ALONG THE NAVKA-DISY PROJECT PREGON-X

Jäger R., Akter N., Gorokhova L., Messmer E.

MODEL- AND SENSOR-INTEGRATION FOR AN INTEGRATED

3D GEOMONITORING IN A MODERN DATA COMMUNICATION

STRUCTURE WITH APPLICATIONS TO THE STUTTGART TV TOWER

Ješkins J., Karušs J., Zandersons V.

ATVËRTĀ KODA LIDAR SISTËMAS IZVEIDE SPELEOLOGISKIEM PËTİJUMIEM 
Kluga A., Kluga J.

ANALYSIS OF DETERMINATION METHODS OF DYNAMIC OBJECT MOTION PARAMETERS

Krutova U.

AUGSTAS DETALIZĀCIJAS ĢEOTELPISKĀS INFORMĀCIJAS

PROBLËMJAUTĀJUMI

Morozova K.

IMPORVEMENT OF QGEOID OF LATVIA

Nikuḷins V.

SEISMOTECTONIC PREREQUISITES

FOR THE GEODYNAMIC HAZARD OF LATVIA

Normand M.

SPACE WEATHER AND GNSS OBSERVATIONS

Segliņš V., Kukela A., Lazdin,a B.

THE RUINS OF ANCIENT STONE STRUCTURES ON THE ISLANDS

OF THE FIRST CATARACT OF NILE IN EGYPT

Seker D. Z.

USE OF UNMANNED AERIAL VEHICLE (UAV) FOR COASTAL ZONE MANAGEMENT: A CASE STUDY OF TERKOSERKOS

Silabriedis G.

RESEARCH ACTIVITIES AT THE INSTITUTE OF GEODESY AND GEOINFORMATICS

Varna I., Balodis J.

SPACE WEATHER AND EARTHQUAKE INFLUANCE ON GNSS

SOLUTIONS 


\title{
DEVELOPMENT OF NATIONAL MEASUREMENT SYSTEM FOR STRUCTURAL HEALTH MONITORING
}

\author{
B. Akpinar \\ Yildiz Technical University, Civil Engineering Faculty, Department of Geomatics \\ Engineering 34220 Esenler, Istanbul, Turkey \\ E-mail: bakpinar@yildiz.edu.tr
}

Structural Health Monitoring (SHM) systems have been gaining popularity in the natural disaster-prone regions in order to mitigate the risks and also minimize the economic losses. In addition to the natural disasters, the local site effects (relative ground settlement, insufficient structural systems) may also cause the risk on the structural systems even during the construction phase. Therefore, there is a need to monitor the engineering structures during the construction and in-service life. In the literature, the SHM systems and the algorithms processing the data have been increasingly available. The fundamental of SHM systems rely on the data acquired from the sensors placed on the engineering structures such as bridges, high-rise buildings etc. The sensors placed on the structures for shortterm (campaign) or long-term (embed) basis are the most critical part of the SHM procedure. This study is representing the results of an ongoing TUBITAK 1005 project titled as "Design and Development of National Measurement System for SHM" (115Y250). The project is an important example of the collaboration between Geomatics, Electric-Electronics and Civil Engineering researchers. Within the scope of this paper, the researchers will demonstrate the results of the dynamic tests being conducted on shake-table. The preliminary results of the on-going tests are future-promising in terms of the design and development of national measurement system in SHM studies. 


\title{
ANALYSIS OF CORS POSITIONING RESULTS FOR IMPROVEMENT OF GNSS/LEVELLING POINT ELLIPSOIDAL HEIGHT ACCURACY
}

\author{
J. Balodis' ${ }^{1}$ I. Vārna ${ }^{1}$, D. Haritonova' ${ }^{1}$, M. Normand ${ }^{1}$, ${ }^{2}$ I. Jumare ${ }^{1}$ \\ ${ }^{1}$ University of Latvia, Institute of Geodesy and Geoinformatics \\ ${ }^{2}$ Riga Technical University, Faculty of Building and Civil Engineering \\ E-mail: janis.balodis@lu.Iv
}

\begin{abstract}
The objective of this paper is to check the reliability of the 4-hour GNSS static observations at the continuously operating reference stations (CORS). Obviously, they are mainly affected by space weather and less affected by multipath due to the predominantly highly elevated placement of antennas which are not obstructed by trees or various constructions. The GNSS daily observation records which are split in 4-hour records and additionally each of them split in 48 records. Each newly obtained record processed. The results of average values from 48 5-minute kinematic solutions (5-min) compared with solutions of corresponding 4 hour $(4 \mathrm{~h})$ continuous static observation solution results. The $4 \mathrm{~h}$ static observation record split in 485 -min records gives the one of possibilities to follow the GNSS signal mitigation affected by space weather fluctuations and/or by multipath.

\section{Introduction}

It had been discovered by many researchers and institutions that sunspots and huge solar flares are the mean sources for the unexpected space weather performances affecting the radio signal propagation in outer space of the Earth $(\operatorname{WEB}(a), \operatorname{WEB}(b))$. The space weather affected by geomagnetic storms is a most important error source in GNSS related positioning tasks (Astafyeva et al., 2015; Cherniak et al., 2015). One of these tasks is the determination of ellipsoidal heights (h) for so called GNSS/levelling points which are used to tie the gravitational geoid model to the framework of national levelling network (Morozova et al., 2017). GNSS 4h static observations have been carried out by the staff of the Institute of Geodesy and Geoinformatics (GGI) at the sites of GNSS/levelling points. The positioning reduction has been performed in the framework of EUREF reference network EPN (WEB(c)) by using Bernese 5.2 software (Dach et al., 2015). The continuously operating reference station (CORS) networks LatPos (Zvirgzds, 2005; WEB(d)) and EUPOS-Riga (Balodis et al., 2010; WEB(e)) are used for analysis of accuracy of 4h GNSS static observation results which are used in GGI for quasi-geoid modelling.
\end{abstract}




\section{Samples of the scintillation}

There were no strong geomagnetic storms in December 2016 (Table 1). The GNSS observations at the Latvian CORS stations in December 2016 has been chosen for analysis of both $4 \mathrm{~h}$ and 5-min GNSS observations. According the Table $1 \mathrm{Ap}$ index is rather low and $\mathrm{Kp}$ index just occasionally exceed 5+ which is a threshold to observe the aurora in Latvian latitudes.

\begin{tabular}{|c|c|c|c|c|c|c|c|c|c|c|c|}
\hline$\#$ & Date & Ap & $\mathbf{0 0 - 0 3 h}$ & $\mathbf{0 3 - 0 6 h}$ & $\mathbf{0 6 - 0 9 h}$ & $\mathbf{0 9 - 1 2 h}$ & $\mathbf{1 2 - 1 5 h}$ & $\mathbf{1 5 - 1 8 h}$ & $\mathbf{1 8 - 2 1 h}$ & $\mathbf{2 1 - 0 0 h}$ & Kp max \\
\hline 1 & 2016.12 .08 & $\mathbf{2 1}$ & $3+$ & 4 & $3-$ & $3-$ & $3-$ & 4 & $4+$ & 4 & $4+$ \\
\hline 2 & 2016.12 .09 & $\mathbf{2 4}$ & 4 & 2 & $3+$ & $4-$ & 3 & $4-$ & $5-$ & $5-$ & $5-$ \\
\hline 3 & 2016.12 .21 & $\mathbf{2 3}$ & 2 & 2 & $1+$ & 3 & $3+$ & 6 & 4 & 4 & 6 \\
\hline 4 & 2016.12 .22 & $\mathbf{2 2}$ & $5-$ & $4+$ & $3+$ & 3 & 3 & $3-$ & 4 & 3 & $5-$ \\
\hline 5 & 2016.12 .23 & $\mathbf{1 9}$ & 3 & 4 & $3-$ & $3+$ & 3 & $3+$ & 4 & $4-$ & 4 \\
\hline 6 & 2016.12 .25 & $\mathbf{2 0}$ & $3+$ & $3+$ & 2 & $4-$ & 4 & 4 & 4 & $3-$ & 4 \\
\hline 7 & 2016.12 .26 & $\mathbf{2 0}$ & $5-$ & $3+$ & $3+$ & 3 & $4-$ & $4-$ & $3-$ & $3+$ & $5-$ \\
\hline
\end{tabular}

Table 1. Geomagnetic storms in December 2016 (WEB(f))

The phenomena of GNSS scintillation is checked at the Latvian CORS stations LatPos and EUPOS ${ }^{\circ}$-Riga by performing the kinematic 5-minute GNSS observations (Balodis et al., 2017) and by searching the disturbed results in this monthly set of computed results presented in Table 2 .

\begin{tabular}{|c|c|c|c|c|c|c|c|c|c|c|c|c|c|c|c|}
\hline \# & & Date & & & Time & & $\min$ & & & & Dor & & & & \\
\hline 1 & 2016 & Dec & 2 & 21:35 & 23:15 & UT & 100 & KREI & VAIV & & & & & & \\
\hline 2 & 2016 & Dec & 5 & 10:25 & $10: 30$ & UT & 5 & PREI & & & & & & & \\
\hline 3 & 2016 & Dec & 5 & 11:05 & 11:10 & UT & 5 & PLSM & & & & & & & \\
\hline 4 & 2016 & Dec & 5 & 11:25 & 11:30 & UT & 5 & REZ1 & & & & & & & \\
\hline 5 & 2016 & Dec & 7 & $9: 50$ & 9:55 & UT & 5 & DOB1 & LIPJ & LIMB & IRBE & & & & \\
\hline 6 & 2016 & Dec & 8 & 20:25 & $20: 30$ & UT & 5 & PREI & & & & & & & \\
\hline 7 & 2016 & Dec & 8 & $20: 50$ & $20: 55$ & UT & 5 & PLSM & & & & & & & \\
\hline 8 & 2016 & Dec & 8 & 21:25 & 21:30 & UT & 5 & SALP & KREI & LUNI & VAIV & REZ1 & SIGU & SLD1 & VANG \\
\hline 9 & 2016 & Dec & 8 & 23:35 & 23:40 & UT & 5 & BAUS & DAU1 & & & & & & \\
\hline 10 & 2016 & Dec & 10 & 7:05 & $7: 10$ & UT & 5 & MADO & LODE & & & & & & \\
\hline 11 & 2016 & Dec & 11 & 16:45 & 16:50 & UT & 5 & PREI & & & & & & & \\
\hline 12 & 2016 & Dec & 11 & 17:05 & $17: 10$ & UT & 5 & PLSM & & & & & & & \\
\hline 13 & 2016 & Dec & 11 & $17: 40$ & $17: 45$ & UT & 5 & REZ1 & & & & & & & \\
\hline 14 & 2016 & Dec & 12 & $7: 55$ & $8: 05$ & UT & 10 & KREI & VAIV & & & & & & \\
\hline 15 & 2016 & Dec & 13 & $3: 20$ & $3: 25$ & UT & 5 & MADO & LODE & & & & & & \\
\hline 16 & 2016 & Dec & 14 & $16: 40$ & $16: 45$ & UT & 5 & PREI & & & & & & & \\
\hline 17 & 2016 & Dec & 14 & $17: 35$ & $17: 40$ & UT & 5 & REZ1 & & & & & & & \\
\hline 18 & 2016 & Dec & 15 & 11:45 & $12: 35$ & UT & 50 & KREI & VAIV & VANG & & & & & \\
\hline 19 & 2016 & Dec & 18 & $8: 30$ & $8: 35$ & UT & 5 & KREI & VAIV & & & & & & \\
\hline 20 & 2016 & Dec & 18 & $10: 30$ & $10: 35$ & UT & 5 & DOB1 & JEK1 & LIPJ & LIMB & IRBE & & & \\
\hline 21 & 2016 & Dec & 20 & 2:50 & $2: 55$ & UT & 5 & LIPJ & IRBE & & & & & & \\
\hline 22 & 2016 & Dec & 23 & 10:25 & $10: 30$ & UT & 5 & LODE & & & & & & & \\
\hline 23 & 2016 & Dec & 23 & 11:10 & 11:15 & UT & 5 & MADO & & & & & & & \\
\hline 24 & 2016 & Dec & 25 & 14:00 & 14:05 & UT & 5 & LIPJ & IRBE & & & & & & \\
\hline 25 & 2016 & Dec & 27 & 11:15 & 11:20 & UT & 5 & DOB1 & JEK1 & LIPJ & LIMB & IRBE & & & \\
\hline 26 & 2016 & Dec & 27 & 21:05 & 21:10 & UT & 5 & PREI & & & & & & & \\
\hline 27 & 2016 & Dec & 27 & 22:00 & 22:05 & UT & 5 & REZ1 & & & & & & & \\
\hline 28 & 2016 & Dec & 28 & $22: 50$ & 22:55 & UT & 5 & PREI & & & & & & & \\
\hline
\end{tabular}

Table 2. Scintillation sequence at the CORS stations in DEC 2016 
The occasional disturbed results fixed mostly near the dawn and after the dusk. In $8^{\text {th }}$ December simultaneously in 8 station observations were fixed disturbed results exceeding the threshold of $10 \mathrm{~cm}$ in at least one of North, East, Up components.

\section{Comparison of $4 \mathrm{~h}$ results with averaged 48 of 5-minresults}

The data set of 30 Latvian CORS stations (S) and the GNSS observation records were selected for 30 days of December 2016. The data static mode processing has been performed by using Bernese software 5.2 and EUREF reference data for all of the set $4 \mathrm{~h}$ GNSS observation records (900 solutions $\mathrm{x}_{\mathrm{i}, \mathrm{j}}, \mathrm{y}_{\mathrm{i}, \mathrm{j}}, \mathrm{h}_{\mathrm{i}, \mathrm{j}}$ ). Set $\mathrm{S}$ coordinates belongs to the epoch 2015.0, set $4 \mathrm{~h}$ belongs to different epochs of December 1 till December $30, \mathrm{n}=30$.

$$
\begin{aligned}
& X_{i}, Y_{i}, H_{i} \in S, \quad i=1, \ldots, 30 \\
& x_{i j}, y_{i j}, h_{i j} \in 4 h, j=1, \ldots, n
\end{aligned}
$$

The kinematic mode (KIN) solutions (Dach et al., 2015). for all of the subset KIN of set 5 -min observation records (43200 solutions $\left.\mathrm{x}_{\mathrm{i}, \mathrm{k} \mathrm{k}}^{\prime}, \mathrm{y}_{\mathrm{i}, \mathrm{k}, \mathrm{j}}^{\prime}, \mathrm{h}_{\mathrm{i}, \mathrm{j}, \mathrm{k}}^{\prime}(3)\right)$ by using Bernese software 5.2 and EUREF reference data.

$$
x_{i j k}^{\prime}, y_{i j k}^{\prime}, h_{i j k}^{\prime} \in K I N, \quad k=1, \ldots, 48
$$

The average values have been computed (4) for all the sets of 48 5-min solutions, correspondingly.

$$
\begin{aligned}
& \bar{h}_{i j}=\frac{\sum_{k=1}^{48} h_{i j k}^{\prime}}{48}, \quad \bar{h}_{i j} \in 5-\mathrm{min} \\
& \sigma_{i}=\sqrt{\frac{\sum_{j=1}^{n}\left(h_{i j}-H_{i}\right)^{2}}{(n-1)}}, \quad \sigma \in 4 h \\
& \sigma_{i}^{\prime}=\sqrt{\frac{\sum_{j=1}^{n}\left(\bar{h}_{i j}-H_{i}\right)^{2}}{(n-1)}}, \sigma^{\prime} \in 5-\min
\end{aligned}
$$

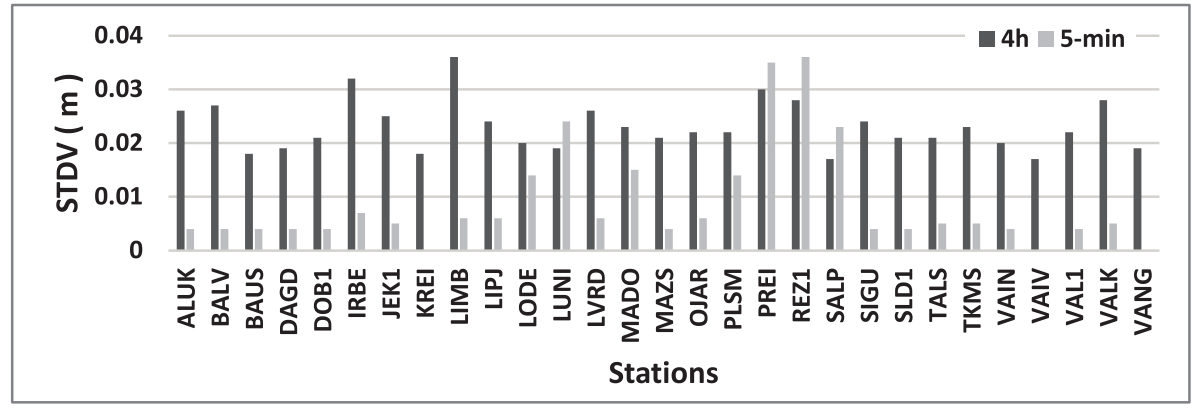

Fig. 1. Comparison of 4h Up STDV $(\sigma)$ and STDV $\left(\sigma^{\prime}\right)$ of average of 5 -min solutions Up. KREI, VAIV and VANG 48 5-min solutions are excluded. 
The monthly standard deviations have been computed for both sets of solutions 4h (5) and 5-min (6). The results are depicted in Fig. 1.

There were too large discrepancies in few Up component values in KREI, VAIV and VANG stations, correspondingly. The most attention in this research is paid to the Up component. In Fig. 2 is depicted the amplitude of $h_{\max }-h_{\min }$ for each of the station, correspondingly. In Fig. 3 are depicted the differences in Up component results which doesn't exceed $8 \mathrm{~mm}$ even for stations KREI, VAIV and VANG.

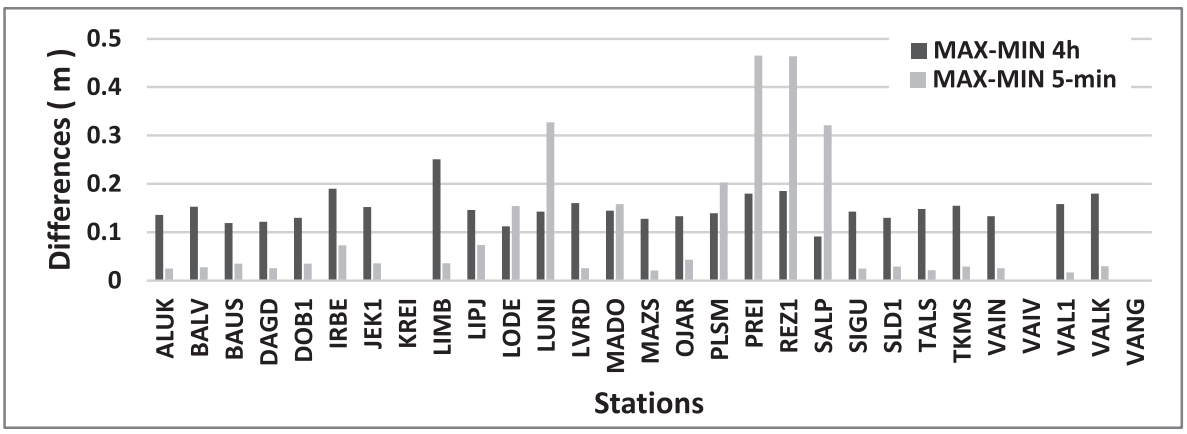

Fig. 2. Comparison $h_{\max }-h_{\min }$ between 4 h solution and average of 485 -min KIN solutions. KREI, VAIV and VANG 485 -min solutions are excluded.

Estimating the data in Fig. 2 the conclusion is that results of the set 5-min has a larger dispersion of amplitudes $h_{\max }-h_{\min }$. Almost all the Up differences (Fig. 3) are positive. The differences are less than $1 \mathrm{~cm}$.

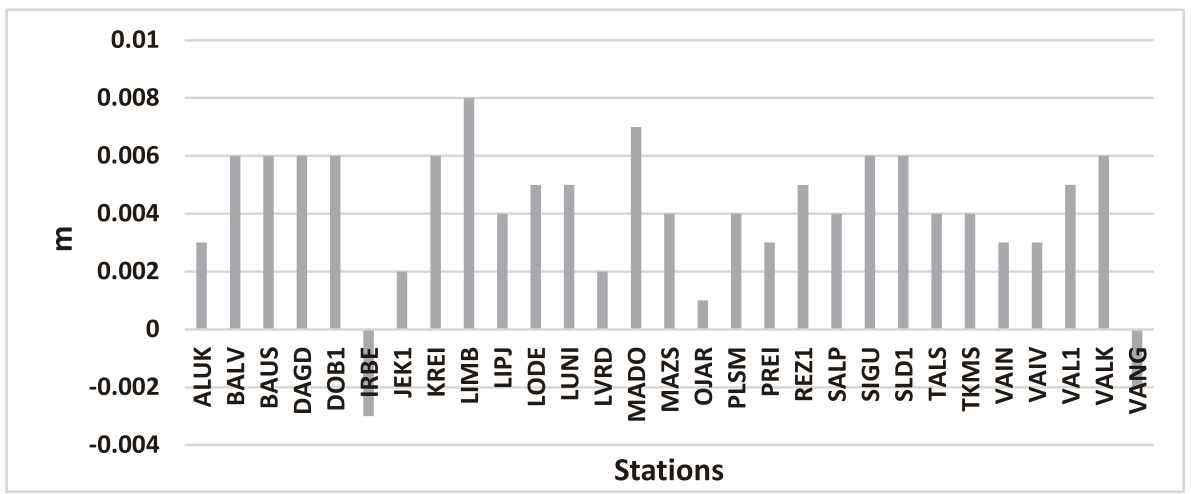

Fig. 3. Up differences between $4 \mathrm{~h}$ and average of 5-min solutions.

\section{$10 \mathrm{~cm}$ threshold for 5 -min KIN solutions}

The attempt to increase the precision of 5-min average has been applied by avoiding outlying values of 5-min subset KIN solutions with a threshold of $10 \mathrm{~cm}$ 
in a subsets of 48 solutions. The comparison of repeatedly obtained standard deviations is depicted in Fig.8-10. The improvements are meaningful because the space weather affected KIN solutions are avoided now. Even KREI, VAIV and VANG 5-min solutions are of good quality now (Fig. 4).

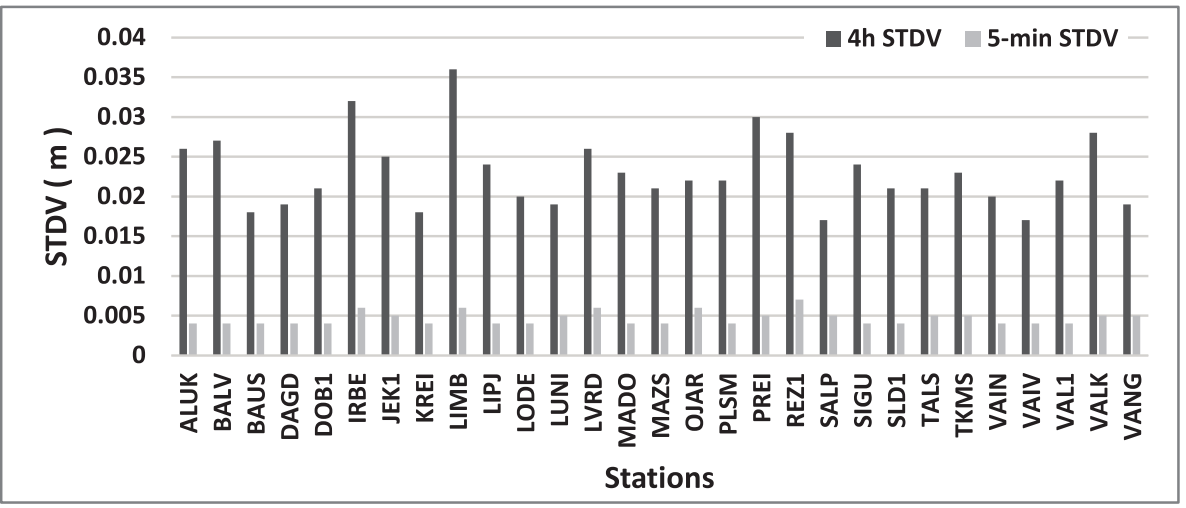

Fig. 4. Comparison of 4h Up STDV $(\sigma)$ and STDV $\left(\sigma^{\prime}\right)$ of average of $5-\min 10 \mathrm{~cm}$ threshold solutions Up.

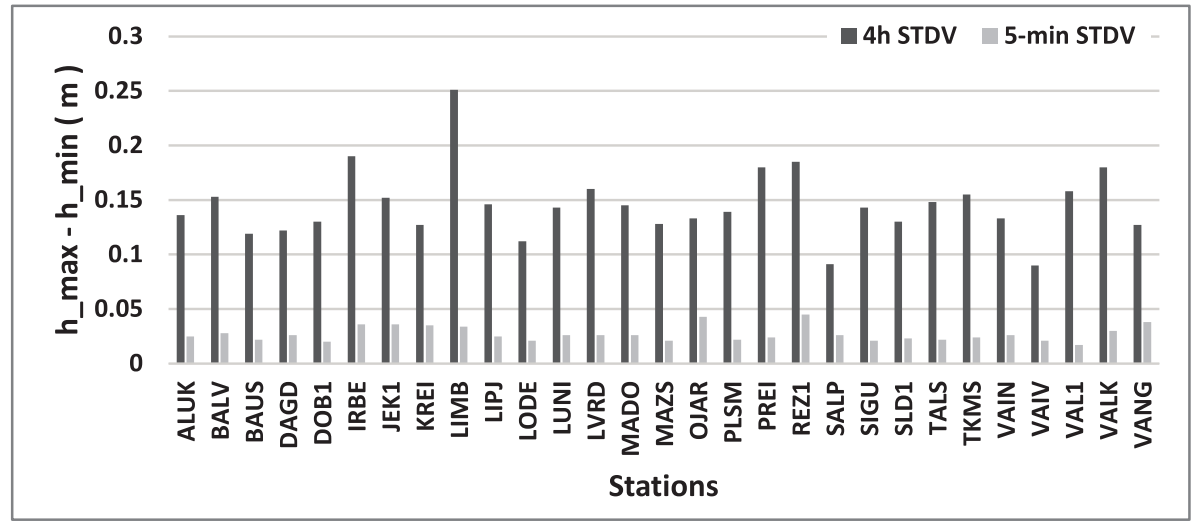

Fig. 5. Comparison of $h_{\max }-h_{\min }$ between $4 h$ solution and average of 48 5-min KIN $10 \mathrm{~cm}$ threshold solutions.

\section{Conclusions}

The solutions of the 5 -min set where the space weather influence is minimized are unfalteringly gives the best final results. The improvement of 5-min solutions clearly visible by comparing Fig. 2 and Fig. 5 .

The mathematical GNSS observation reduction by using Bernese 5.2 software gives better results when observation record is splitted and kinematic reduction 
method is applied. It gives opportunity to avoid outlying observation results influenced by space weather and possibly multipath as well.

\section{Acknowledgements}

The research was developed under the contract ERAF Nr. 1.1.1.1/16/A/160.

\section{REFERENCES}

1. Astafyeva, E., Zakharenkova, I., Förster, M. (2015). Ionospheric response to the 2015 St. Patrick's Day storm: A global multi-instrumental overview, In: J. Geophys. Res. Space Physics, 120, 9023-9037, DOI:10.1002/2015JA021629.

2. BALODIS J, VARNA I, HARITONOVA D, NORMAND M, SILABRIEDIS G. 2017. Ground Based Kinematic GNSS Observation Results Affected by Space Weather Fluctuations in 2015. Baltic Journal of Modern Computing. University of Latvia. Vol. 5 (2017) No. 3. 251-268. ISSN 2255-8950 (online). ISSN 2255-8942 (Print). http://www.bjmc.lu.lv/ http://www.bjmc.lu.lv/fileadmin/user_upload/lu_portal/ projekti/bjmc/BJMC_Cover_400.jpg

3. Balodis, J., Silabriedis, G., Caunite M., Janpaule, I., Balodis, K., Rubans, A., Aleksejenko, I., Otto, R., Ratkus, B., Reiniks, M., Mitrofanovs, I., Plotnikovs, S., Zvirgzds, J. EUPOS $^{\circledR}$-RIGA NETWORK ELEVATION ANALYSES. International Symposium on Global Navigation Satellite Systems, Space-Based and Ground-Based Augmentation Systems and Applications, Berlin, Germany, 30 November - 2 December 2009; Conference Proceedings. Senate Department for Urban Development, Berlin, Germany 2010; Publication ISBN 978-3-938373-93-4; p. 68-72.

4. Cherniak, I., Zakharenkova, I., Redmon, R.J. (2015). Dynamics of the highlatitude ionospheric irregularities during the 17 March 2015 St. Patrick's Day storm: ground-based GPS measurements, In: Space Weather, 13 (9), 585-597, DOI:10.1002/2015SW001237.

5. Dach, R., Lutz, S., Walser, P., Fridez, P. (2015). Bernese GNSS Software Version 5.2. Astronomical Institute, University of Bern, Bern, Switzerland. 852 p.

6. Morozova Katerina, Ansis Zarins, Janis Balodis, Augusts Rubans, Reiner Jaeger. 2017. Digital zenith camera's results and its use in dfhrs v.4.3 software for quasi-geoid determination. Proceedings, 2017 Baltic Geodetic Congress (Geomatics). Gdansk University of Technology, 22-25 June 2017, Poland. 978-1-5090-2421-6/\$31.00 @2016 IEEE p. 174-178. DOI10.1109/BGC.Geomatics.2017.74

7. Zvirgzds J. 2005. Global positioning system permanent base station network in Latvia. Scientific Proceedings of Faculty of Civil Engineering, Riga Technical University, ISSN 0984-32-694-2. Pp 51-57.

8. WEB (a) NOAA 2018. Space weather prediction center. National Oceanic and Atmospheric Administration. http://www.swpc.noaa.gov/products/goes-x-ray-flux

9. WEB (b) ESA space weather awareness. 2017. http://swe.ssa.esa.int/

10. WEB (c) EUREF permanent GNSS network. http://www.epncb.oma.be/

11. WEB (d) LatPos. 2018. http://map.lgia.gov.lv/index.php?lang $=0 \& c P a t h=2 \& t x t \_i d=13$

12. WEB (e) EUPOS-RİGA I RDPAD. 2018. http://www.rdpad.lv/geotelpiska-informacija/ eupos-riga/

13. WEB (f) SpaceWeatherLive.com https://www.spaceweatherlive.com/en/auroral-activity/ top-50-geomagnetic-stormsf 


\title{
SATELLITE IMAGERY FOR OPERATIONAL ACQUIRING AND ANALYSIS OF FOREST INFORMATION, AND PLANNING OF SUSTAINABLE ACTIVITIES IN VAST FOREST AREAS
}

\author{
I. Barga ${ }^{1}$ \\ 1 Baltic Satellite Service, Ltd. \\ E-mail: ilze@baltsat.Iv
}

In Latvia, more than half of territory is forest and there are around 150000 private forest owners who manage half of all Latvian forests with about $15000 \mathrm{~km}^{2}$ in total. Results of research on private forest potential "Assessment of private forest potential contribution to Latvian timber industry 2011-2015" show that on average $25 \%$ of forest owners, but in big forest estate groups more than $60 \%$ of forest owners, do not live on their forest property. Therefore, easy accessible and intuitive forest monitoring system where satellite imagery provides current data about forest properties, automatically detects changes and presents soil moisture information is critical to a big number of forest owners in Latvia.

Sweden has proved that application of Sentinel-2 data in forest management results in direct economic benefit to the country of between $€ 16.1 \mathrm{~m}$ and $€ 21.6 \mathrm{~m}$ per annum (Sawyer et al. 2016). In Latvia forestry is one of the main industries and being able to monitor actual situation with Sentinel-1 and Sentinel-2 imagery could cause positive impact to forest industry in Latvia as well.

Change recognition model which is developed based on Synthetic Aperture Radar (SAR) data from Sentinel-1 uses established techniques such as described in Change detection with synthetic aperture radar (Cihlar et al. 2007) and Change Detection in Synthetic Aperture Radar Images based on Image Fusion and Fuzzy Clustering (Gong et al. 2012) assures weekly data. The automated system detects clear cuts (from $0.25 \mathrm{ha}$ ) and windfalls (from $0.5 \mathrm{ha}$ ) under any weather conditions using radar satellite imagery.

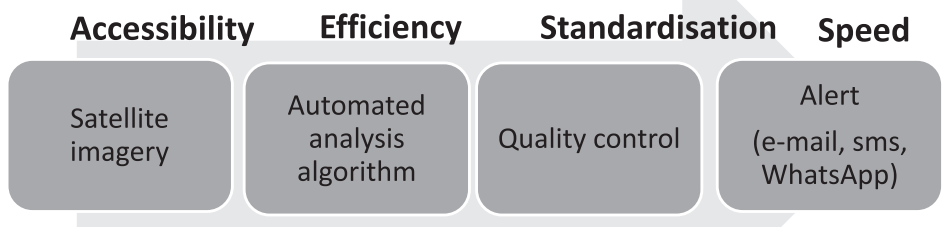

Fig.1. Fast and efficient automated forest alert service 
Automated forest alert service system is a powerful tool for forest management which may inceased economic activity among forest owners in Latvia and improve forest management practice as well as natural forest environment. Application of current satellite imagery data provides forest owners with tools to remotely monitor forest areas, follow the changes, assess potential threats, respond immediately in critical situations, prepare for change in advance as well as better optimize and smarter plan forest management work in accordance with an actual situation.

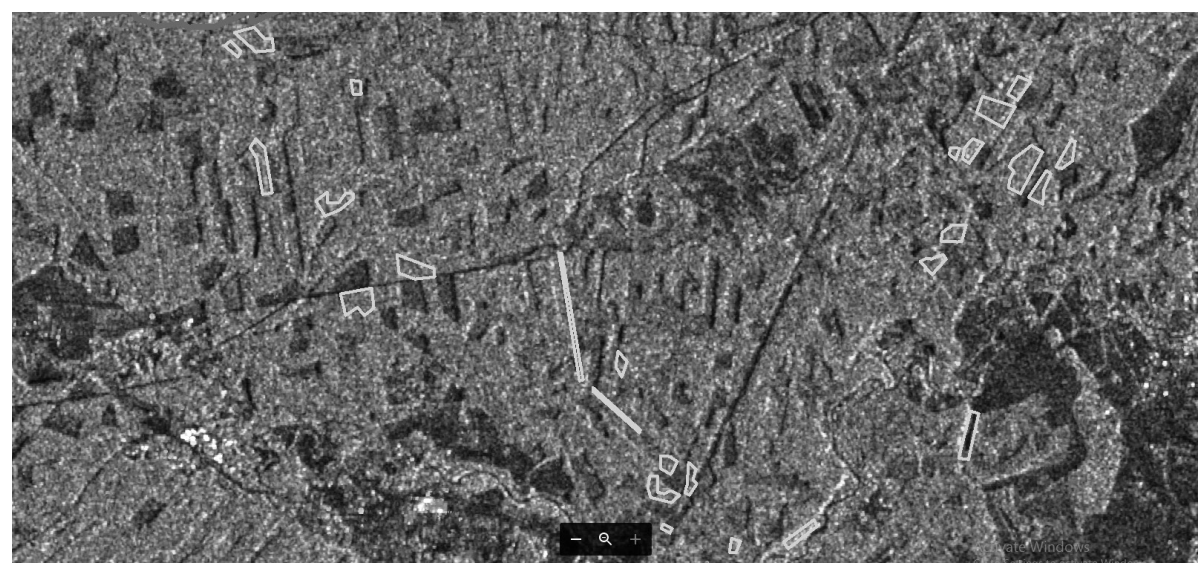

Fig. 2. Detected clear cuts - radar image example

Taking into account high competition in the global forest market it is critical to use forest management techniques helping to improve efficiency and increase competitiveness. Earth observation techniques are capable to move into everyday life and offer reliable complementary service of valuable information to forest industry.

\section{REFERENCES:}

1. Cihlar J,Pultz TJ and Gray AL 2007 Change detection with synthetic aperture radar International Journal of Remote Sensing 401-414

2. Gong M, Zhou Z and Ma J 2012 Change Detection in Synthetic Aperture Radar Images based on Image Fusion and Fuzzy Clustering IEEE Transactions of Image Processing: a publication of the IEEE Signal Processing Society 21 (4) 2141-51

3. Sawyer G, Dubost A and de Vries 2016 Copernicus Sentinels' Products Economic Value: A Case Study of Forest Management in Sweden Study report EUROPEAN ASSOCIATION OF REMOTE SENSING COMPANIES 


\title{
3D SHORELINE EXTRACTION FROM DIFFERENT TYPES OF SPATIAL DATA: A CASE STUDY OF TERKOS-ISTANBUL
}

\author{
B. Bayram \\ Yildiz Technical University, Civil Engineering Faculty, \\ Department of Geomatic Engineering 34220 Esenler, Istanbul, Turkey \\ E-mail: bayram@yildiz.edu.tr
}

The periodically monitoring of coastal areas is possible by using spatial data which is low cost and produced rapidly with higher accuracy. For this purpose, different data acquisition techniques have been developed and they are still in use. Nowadays, unmanned aerial vehicles (UAV) began to be used widely. Parallel to the developments in computer and camera systems, especially in the local areas, the UAV's are being accepted as highly accurate and fast data acquisition system.

The presented study focused on shoreline extraction from UAV-LIDAR data to enable sustainable monitoring and management of the coastal areas. An automatic shoreline extraction algorithm has been developed from both UAV-LIDAR data. The developed algorithm based on Mean-shift and Alpha Shapes algorithms. Istanbul/Terkos coastal area has been selected for evaluation and testing of the methods which will be used for the research project, about shoreline extraction with use of UAV-Based LIDAR data in the region of Terkos-Istanbul, which supported by TUBITAK (The Scientific and Technological Research Council of Turkey) with project no. $115 \mathrm{Y} 718$. Study area has been selected $1.5 \mathrm{~km}$ shoreline of Istanbul-Terkos Lake which lie on the Black Sea coastline. Accuracy assessment has been realized by using Digital Shoreline Analysis tool. For this purpose, manually digitized shoreline has been taken as reference data and compared with obtained results. 


\title{
AUTOMATED SURVEYING OF TIMBER ASSORTMENT VOLUMES
}

\author{
M. Cekule, K. Čabs, I. Mitrofanovs, K. Balodis \\ University of Latvia, Institute of Geodesy and Geoinformatics \\ E-mail:maritac@lu.Iv; kaspars.cabs@gmail.com
}

There are different factors contributing to the global warming, including intensive agriculture and deforestation. In order to reduce their impact on the climate change, a transition to the low carbon economy has to take place, and smart forest use is an important part of it. For this path to be consistent and sustainable bioeconomic decisions must be based on scientifically proven data and interdisciplinary researches which include both forestry science and information technologies.

Several authors emphasize that in agriculture, as also in the forest sector the information technology has been introduced with the aim to improve the efficiency and performance of this sector. Information for forest operations is used by selecting the suitable stand, harvesting operation, forwarding, storage and transport wood. Knowledge of information significantly influences planning, organization, control and duration of forestry works (Gallo et al. 2013, Kovácsová P, Antalová M, 2010).

Monitoring and automated methods for commercial log and wood chips volume measurement are gaining their significance in the forest sector, as logging and wood - based energy production is playing an increasing role in the Latvian forest sector (Jonsson et al. 2013). Several scientific institutes study and develop measuring techniques that are used as the basis for timber trade and contracts. For example, the Natural Resources Institute Finland explores new optical measuring techniques for timber and wood products which now provide more accurate information about factors such as the shape and volume of logs and the volumes of wood chips. The results of the researches are used in their forestry businesses. However, this is not the case in Latvia where the timber assortment volume measurement solutions are still time consuming, with a complex organization of work and high costs.

A few IT solutions were developed in GGI, which can be used in different spheres of the national economy. For example, an adaptive software for video data processing and automated analysis are offered for the technology transfer in the forestry sector. Within the framework of an effective collaboration project with JSC "Latvia's State Forests", a methodology and IT solution for the automated survey of timber assortment volume for forestry needs is being developed. 
The IT solution for automatic geometric volume measurement of timber assortment consists of a video processing software, a graphical user interface that provides work with the system, data communication channels with external systems and data storage systems (Fig.1).Video information is obtained from video cameras that simultaneously acquire an image from the four-sided object of the video processing area - the three sides and the top. Depending on the type of the selected operation - either log or wood chips - a video image is prepared offering a possibility for the operator to mark the necessary information and obtain precise measurements of the object being analyzed. The obtained information is transmitted through data communication channels to the external systems in the appropriate format, and is stored in the database, allowing to compare the result of automatic data calculation with the manually obtained result.

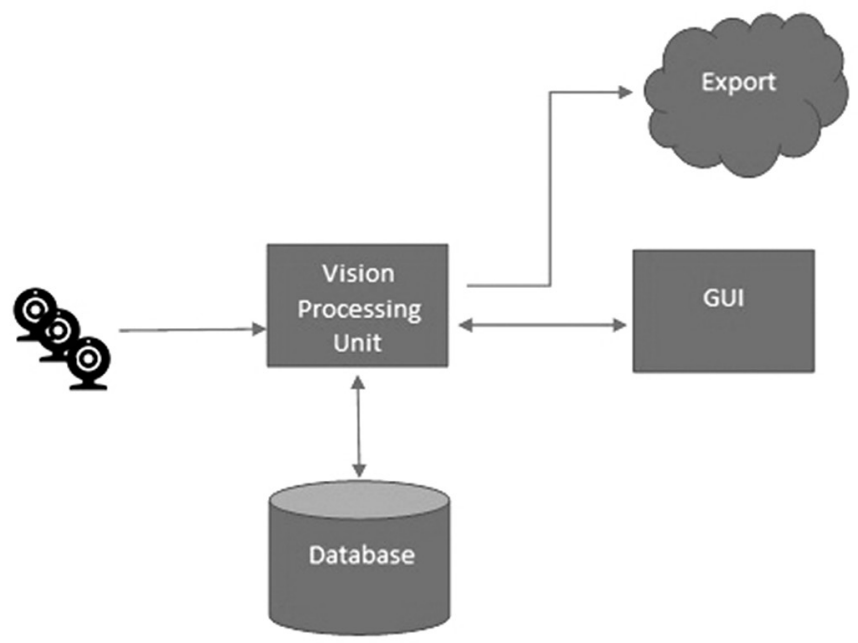

Fig.1. Schematic representation of the timber assortment volumes surveying IT solution.

At the start of the project in laboratory a prototype of the timber assortment volume measurement line with cameras and light layout was created. The angle and lighting for cameras were fixed, as well as specifications of cameras and lights were defined. The obtained video was analyzed with video file analysis software to get the best camera location in field conditions and dimensions of the measuring arch. Log and wood chips load models were used in tests (Fig.2). 


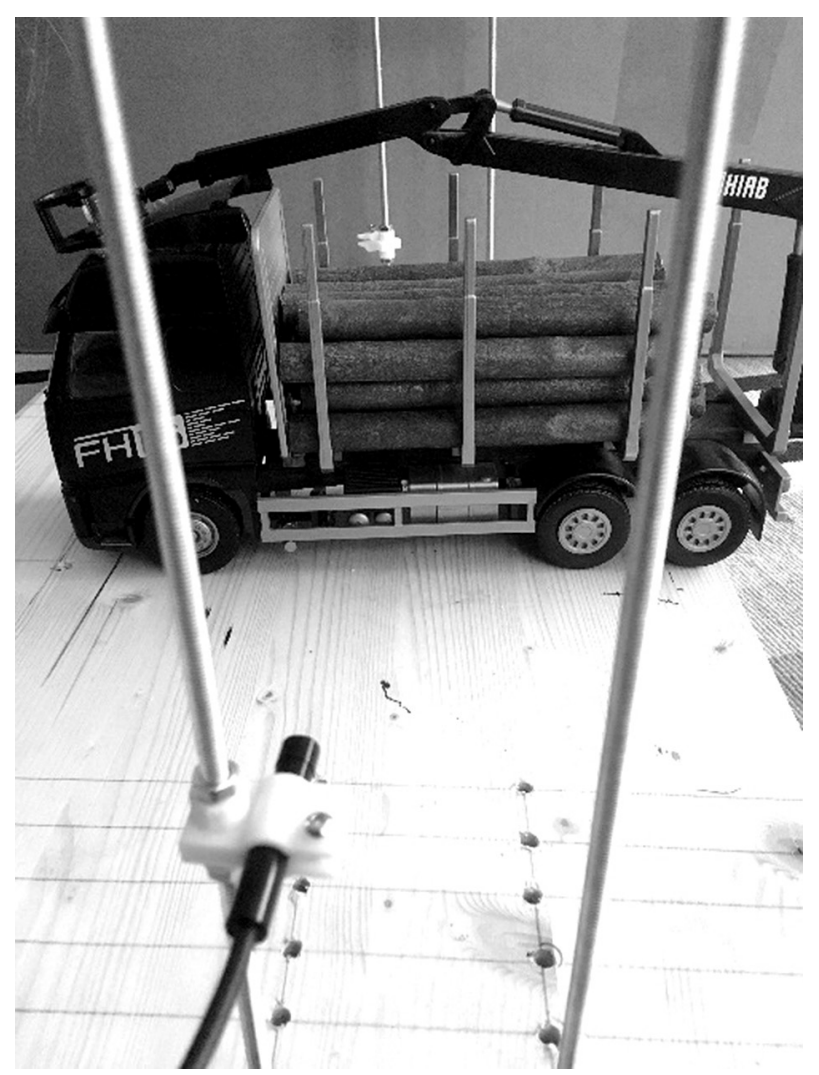

Fig. 2. Prototype with log model test.

\section{REFERENCES:}

1. Gallo R, Grigolato S, Cavalli R, Mazzetto F. 2013. GNSS-based operational monitoring devices for forest logging operation chains. Journal of Agricultural Engineering 2013; volume XLIV(s2): e27, pp. 140-144

2. Kovácsová P, Antalová M. 2010. Precision forestry - definition and technologies. Šumarski list br. 11-12, CXXXIV, pp. 603-611

3. Jonsson R, Mustonen M, Lundmark T et al. 2013. Conditions and prospects for increasing forest yield in Northern Europe. Working Papers of the Finnish Forest Research Institute. http://www.metla.fi/julkaisut/workingpapers/2013/mwp271.htm

4. https://www.luke.fi/en/services/the-forest-industry/ 


\title{
BALDONE SCHMIDT TELESCOPE FUTURE PROSPECTS
}

\author{
I. Eglītis, M. Ābele, R. Eglītis, V. Eglīte \\ University of Latvia, Institute of Astronomy \\ E-mail: ilgmars.eglitis@/u.Iv
}

Schmidt telescopes are used to produce high-quality large fields star images, which in many ways outweighs all other telescopes with similar aperture diameters. During the time period from 1947 to 2005, Schmidt telescopes were the main tool for professional photography of stars and other space objects. Now, these telescopes are no longer optimally used in the world, due to the technological transition to electronic sensors for the use of space imaging. Schmidt cameras have very strongly curved focal planes, thus requiring that detector be correspondingly curved, therefore in the past, the photographic astroplates on which the stellar images were captured were curved, whereas the currently produced sensor matrixes have a flattened surface, and this discrepancy makes it impossible to obtain a high-quality image on a large-sized CCD sensor.

Technologically going to a new type of image object acquisition, from photography to the use of video sensors, we encounter an unresolved problem how to match the curved large-scale telescope's focal surface with the surface of a flat-light imaging sensor. Because of this reason, about fifty large and high quality telescopes around the world, each worth a number of millions, are not being used properly. So far no one has found a rational solution to this problem. Because of the incompatibility of Schmitt telescope and modern imaging sensor surface form, after the end of the usage of photographs in astronomy, many of these telescopes are standing in an inactivity state, for example, the $1.52 \mathrm{~m} \mathrm{Schmidt}$ system telescope at the European Southern Observatory in Chile.

Currently, it is known that the Anglo-Australian Observatory, who are using the Schmitt system telescope, has installed a big number of optical fibers for many fiber spectrographs in order to solve successfully this problem, but the installation of this system is very complicated and costly.

The team Institute of the Astronomy has succeeded in design and calculation of a small optical circuitry that would enable the Schmidt telescope optical system to be improved by inserting an additional optical system in the telescope, forming a flat telescope focal surface that coincides with the surface of the flat-beam receiver.

This upgrade of optical system makes it possible to use the existing high-field flat-panel video sensors without loss of quality, at relatively low cost, without the expensive Schmidt telescope reconstruction. 
A novel method is demonstrated. We have designed additional optical system integrated into Baldone Schmidt telescope and as a result we got a flat focal plane. We have created telescope with upgraded optical system which include prototype of a 'FlyEye' system. Similar system is displaced in the main focal plane of Baldone Schmidt telescope on cassette holder and it will cover over two square degrees of the sky with the resolution of 0,9 arc sec per pixel.

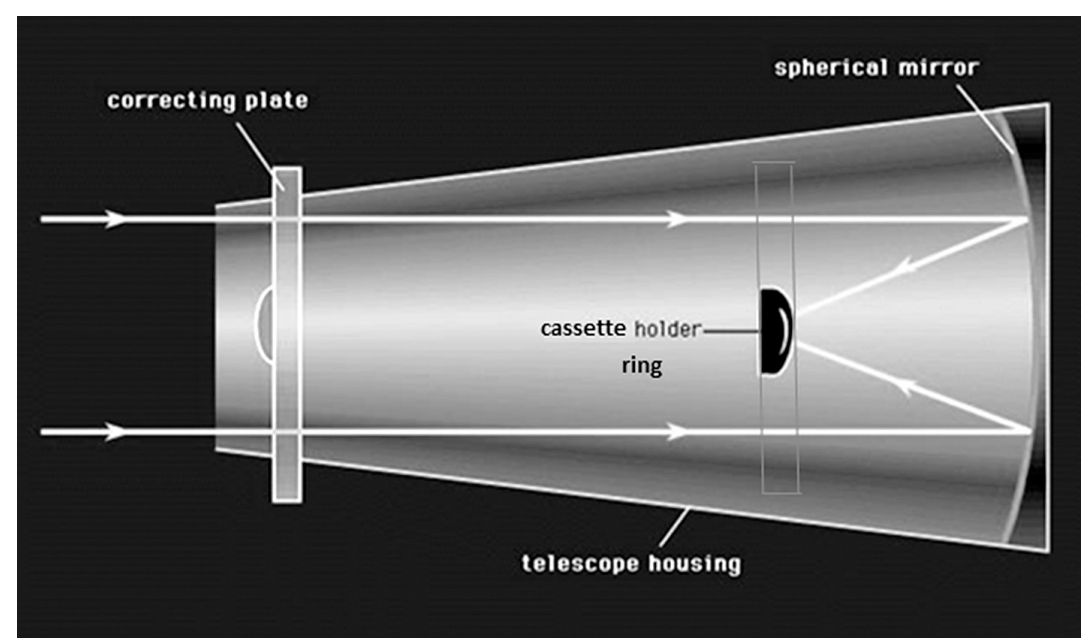

Fig. 1. Schmidt telescope scheme

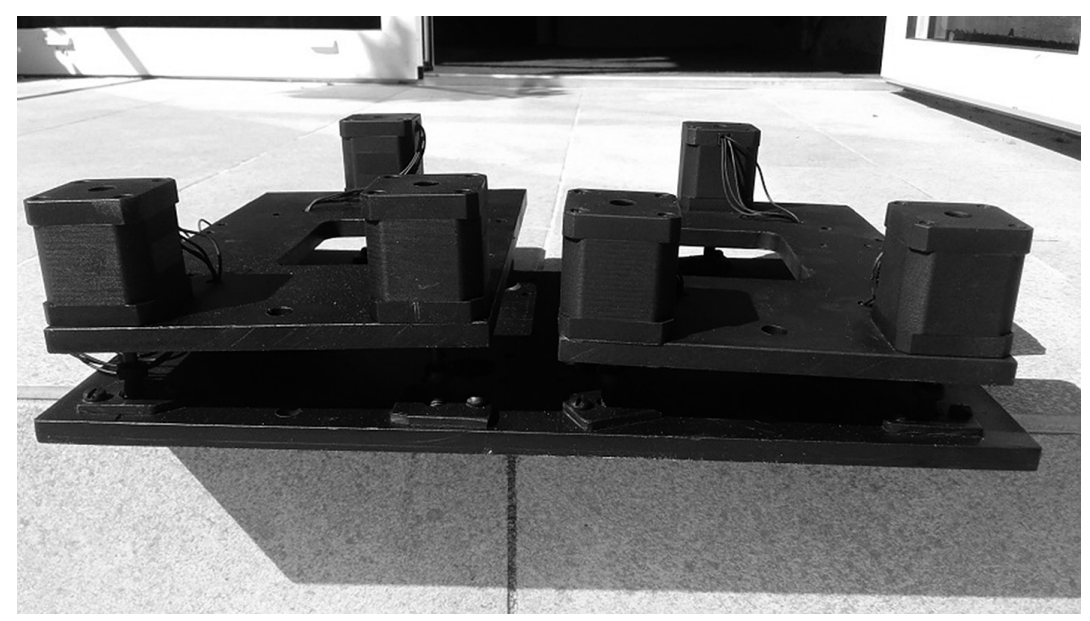

Fig. 2. CCDs holder with steps engines. 


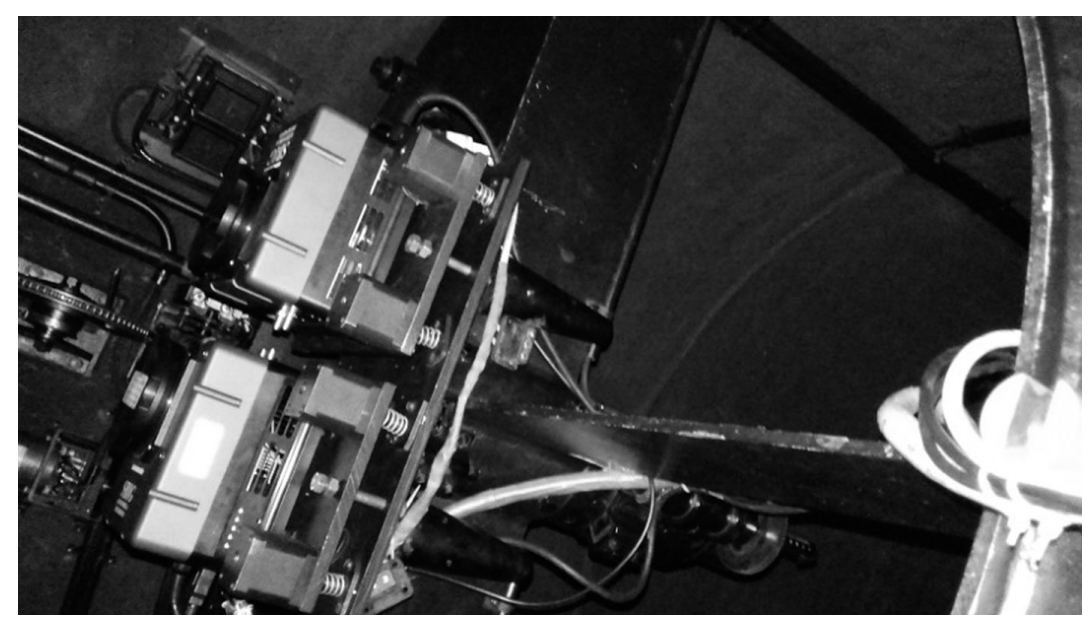

Fig. 3. Two SBIG firm CCDs STX 16803 in the main focus of Baldone Schmidt telescope. 


\title{
MODEL- AND SENSOR-INTEGRATION FOR AN INTEGRATED 3D GEOMONITORING IN A MODERN DATA COMMUNICATION STRUCTURE WITH APPLICATIONS TO THE STUTTGART TV TOWER
}

\author{
L. Gorokhova, N. Akter, R. Jäger, E. Messmer \\ Karlsruhe University of Applied Sciences, Institute of Applied Research (IAF) \\ E-mail: lyudmila.gorokhova@gmail.com
}

The term geo-monitoring comprises different tasks in georesearch, early warning on natural disasters, and the monitoring of structures. The development of new mathematical models, multisensor systems and communication structures in the geomonitoring R\&D project GOCA (aww.goca.info) is pointed along the geomonitoring chain (data acquisition, modelling, reporting and alarm-management).

A first focus is on the mathematical models of the integrated and quasiintegrated 3D-adjustment, which mean a common parameterization of sensor data in the geometry and gravity space in a Gauss Markov model (GMM). The quasiintegrated 3D network adjustment, as being implemented into the GOCA software and system are treated, and its advantages compared to 2D/1D approach, are discussed. Integrated and quasi-integrated 3D adjustment are key models for the parametric integration of all sensor data types in geometry and gravity space (gravimetry, GNSS, total stations, levelling, laser scanners, algorithmically integrated navigation sensors, and optical sensor data up to SAR/INSAR). The observation equations for current sensors are treated. Special attention is given to the GMM for the integration of GNSS/MEMS/MOEMS navigation sensors and algorithm via in-equation restrictions and OSR algorithms.

As concerns integrated 3D geomonitoring (also "System-Analysis", "Structural Health Monitoring (SHM)"), the focus is on finite element models (FEM) for the common parameterization of physical and geometric parameters. FEM is the key to answering the question of whether a monitoring-object is in a "healthy" or an "unhealthy" - meaning dangerous - state. Structural vibration modelling of objects (e.g. for bridges, towers) by the FEM models leads to inverse eigen-value problems, i.e. the task of concluding from changes in the spectral properties of the general eigenvalue problem to changes in the physical state of the object in regard. The TV Tower Stuttgart is presented as a reference object for the above-mentioned innovative $\mathrm{RaD}$ methods for the early detection of hazard potentials of structures (SHM) by new algorithms, sensor systems and information technologies. 
The latter includes a general Internet-based server client for the integrated geomonitoring of monitoring-objects, including the development of Apps for TV tower visitors to visualize the present displacement and vibration state on the visitors smartphone. An online-connection to the geomonitoring server of the TV tower of Stuttgart will be set up during the presentation and the online state will be shown. 


\title{
GEODETIC CHALLENGES ON POSITIONING \& NAVIGATION FOR MOBILE GIS PRESENTED ALONG THE NAVKA-DISY PROJECT PREGON-X
}

\author{
R. Jäger, J. Diekert, S. Janugade and M. Almagboul \\ Karlsruhe University of Applied Sciences, Institute of Applied Research (IAF) \\ E-mail: reiner.jaeger@web.de
}

The research and development (R\&D) project PREGON-X (Precision GNSS and Georeferencing on smartphones, tablets etc. $=\underline{\mathrm{x}}$ ) is funded as a so-called ZIM (Zentrales Innovations programm Mittelstand) project by the German Ministry on Economy and Energy (Bundesministerium für Wirtschaft und Energie). The ZIM funding is generally for small and medium-sized enterprises (SMEs) with business operations in Germany, which want to develop new or significantly improve existing products, processes or technical services. ZIM cooperation projects are between at least one SME and one public or private non-profit research and technology organisation (RTO), acting as a R\&D cooperation partner. Joint transnational ZIM cooperation projects are also possible. In the frame of PREGON-X the R\&D leaded by first author and carried out by the three co-authors as scientific assistants and $\mathrm{PhD}$ candidates, respectively, is on mathematical models, algorithms, software and hardware for precise positioning and non-contact object geo referencing with smartphones as processing and/or sensor unit, up to the $\mathrm{cm}$ level of precision [1].

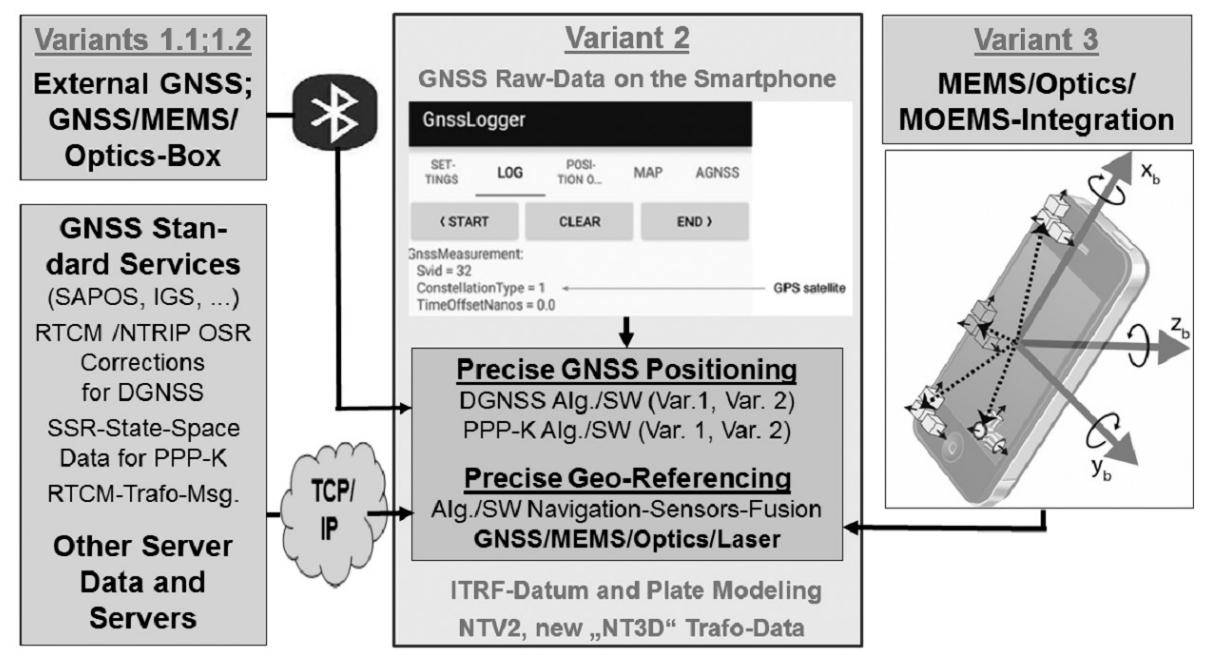

Fig. 1. Variants of the PREGON-X R\&D for Mobile GIS 
The HSKA basic mathematical model, algorithms and software developments are settled in the areas of satellite geodesy (DGNSS, PPP-K based positioning), multisensor navigation (GNSS, MEMS/-accelerometers/-gyroscopes/-magnetometers/-barometers, camera-optics, MOEMS, laser distance measurement unit), and on mathematical and physical geodesy, concerning the matters like datumtransformation, height reference surfaces [3] and geodynamical models. The R\&D results of IAF/HSKA are taken up by the company (SME) Disy, situated also in Karlsruhe (http://www.disy.net), further developed and integrated into innovative smartphone and tablet apps, as well as a component of general TCP/IP server client technologies for mobile GIS, Fig. 1.

Three variants of mobile GIS technologies are developed according to Fig. 1. The variants 1.1 and 1.2 and variant 3 are based on innovative hardware developments in terms of smart positioning and geo-referencing boxes, as further part of the PREGON-X project [1] and the R\&D topics at HSKA. The variant 1.1 carries only a GNSS-receiver and a BT-communication (Fig. 1). So, it is a pure GNSS-positioning-box (for DGNSS and PPP-K), with either a directly mounted smart (5 cm accurate) GPS/Galileo helix antenna or a cable linked external precise geodetic antenna, respectively. As concerns the figured contact-free georeferencing box variant 1.2 (Fig. 1, Fig. 2) the hardware, algorithms and software comprise - in addition to variant 1.1 - the integration and algorithmic multisensor data fusion of the above MEMS and optical sensors (e.g. a camera for

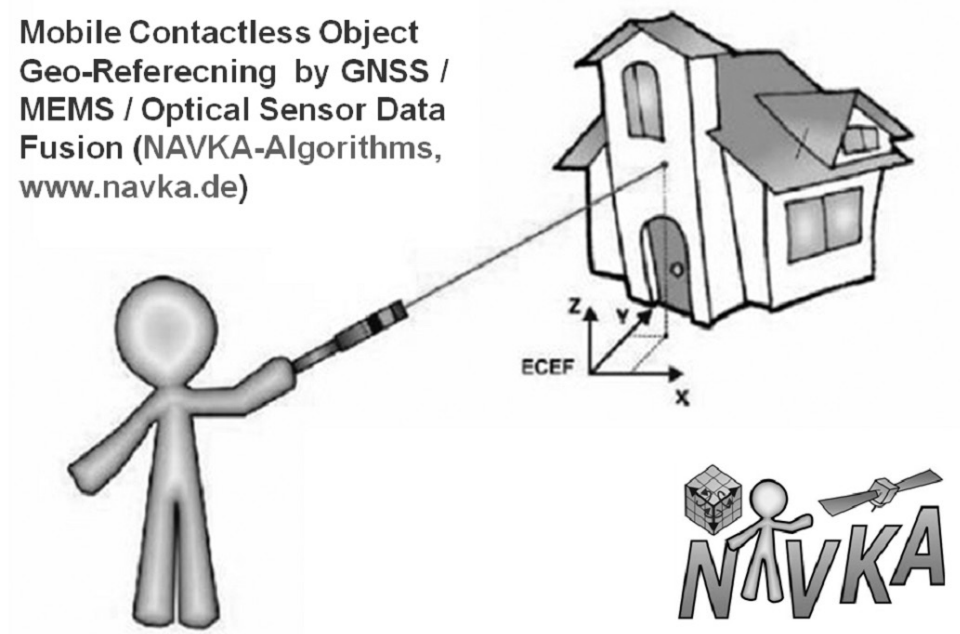

Fig. 2. Mobile Contact-free Object Geo-referencing on Mobile GIS by GNSS/MEMS/Optical Sensor Data Fusion and an additional laser distance-measurement unit 
visual odometry (VO) and indoors physical or virtual marker recognition), and a mounted laser-distance measurement unit. All sensor-components are put into smart compact handheld boxes. The sensor-data for both variants 1.1 and 1.2 is transmitted via BT to the smartphone, which is used as processing, controller and data logging and visualization unit. Variant 2 (Fig. 1) is corresponding to variant 1.1, while the GNSS raw data is in that case from the smartphone, as being available there since end of 2016. Variant 3 (Fig. 1) is corresponding to variant 1.2. In that case all GNSS, MEMS and camera sensor data is taken here from the smartphone sensors, and for geo-referencing (Fig. 2) an additional laser distance measurement unit is docked to the smartphone.

As concerns the developments on innovative mathematical models, algorithms and software for the GNSS component, both DGNSS (Differential GNSS) and PPP-K (Precise Point Positioning in Kinematic mode) algorithms are followed in R\&D at HSKA. In respect to low-cost hardware, and heterogenous antenna types, both cycle-slips and multipath are a typical source of systematic errors. So robust L1-norm estimation, based on SIMPLEX algorithms, and a new type of ambiguity function method are regarded as being appropriate to eliminate or to reduce, respectively the influence of the above error sources. They are therefore part of the R\&D at HSKA and concern both, DGNSS and PPP-K. Further challenges on the satellite geodesy, and the positioning topic for DGNSS and absolute PPP-K positioning are the use of innovative types of linear combinations in the mathematical models, algorithms and software for low-cost L1 GPS, L1/L5 GPS, E1 Galileo and E1/E5 Galileo signals (Code, Phase, Doppler). Problems especially related to globally enabled absolute PPP-K GNSS-positioning are the modeling of geodynamical and relativistic effects. Further the modeling of the troposphere delay, the ionosphere delay, uncalibrated phase delays (UPD) and GNSS differential code biases (DCB). These require the access to external standard PPP-K GNSS and SSR data products services (e.g. the cost free IGS-RTS, or different commercial PPP-K services) and the data of other appropriate servers (Fig.1). To avoid the necessity of a permanent online connection to the internet for accessing these TCP/IP servers (Fig. 1) in mobile GIS applications, alternative concepts are part of the R\&D at HSKA in the frame of PREGON-X.

Further topics and challenges are dealing with the transformation of position data between different ITRFyy_zz.mm related reference frames (yy = year of datum) and the ITRF-related plate stands (zz.mm, zz=year, $\mathrm{mm}=$ month) due to the dynamics of the ECEF (Earth Centered Earth fixed Frame) in respect to the so-called frozen datum and plate stand frames, like the European terrestrial ETRF89_89.00. Above that, the further transformation from the global ITRF to the still in use classical regional national horizontal frames (like DHDN in Germany) and to the height reference surface (geoid or quasi-geoid) are required. For that, either GNSS-services based transmitted local RTCM-transformation 
messages as a world-wide standard [2] can be used (Fig. 1), or complete grids, such as the GIS standard NTV2, which is put on an online server or stored on the local mobile GIS device (smartphone). As NTV2 covers only the horizontal transformation, it will be extended in the frame of PRGON-X to a new and upwards compatible NT3D standard, covering also the transformation of the ellipsoidal height $\mathrm{h}$ to the physical height $\mathrm{H}$.

The GNSS/MEMS/Optical sensor-data fusion in the frame of the variants 1.2 and 3 (Fig. 2) is a further challenge, concerning the research on the mathematical models as a further development of the NAVKA navigation algorithms [2] in respect to the geo-referencing tasks (Fig. 2).

The PREGON-X R\&D means, in general, a technological revolution for ubiquitous systems with sustainable interdisciplinary potentials, which extend beyond the present standard of mobile GIS capacities and precision, and the related geodesy and geoinformatics fields.

\section{REFERENCES:}

1. Reiner Jäger (2010-2018): NAVKA Web-Site: www.navka.de

2. Jäger, R. and S. Kälber (2008): The new RTCM 3.1 Transformation Messages Declaration, Generation from Reference Transformations and Implementation as a Server-Client-Concept for GNSS Services. RTCM Paper 110-2008-SC104-508. RTCM Commission, USA.

3. R. Jäger (2000-2018): DFHRS Web-Site: www.dfhbf.de 


\title{
MODEL- AND SENSOR-INTEGRATION FOR AN INTEGRATED 3D GEOMONITORING IN A MODERN DATA COMMUNICATION STRUCTURE WITH APPLICATIONS TO THE STUTTGART TV TOWER
}

\author{
R. Jäger ${ }^{1}$, N. Akter ${ }^{1}$, L. Gorokhova ${ }^{1}$, E. Messmer² \\ ${ }^{1}$ Karlsruhe University of Applied Sciences, Institute of Applied Research (IAF) \\ 2 Ingenieurbüro Messmer, Schwaikheim, Germany \\ E-mail: reiner.jaeger@goca.info
}

The term geomonitoring combines a variety of tasks in geo-research early warning in the event of natural disasters, and the monitoring of building structures. The developments of new mathematical models, multi-sensor systems and communication structures in the Geomonitoring R\&D project GOCA are presented along the geomonitoring chain (data acquisition, modeling, reporting and alarm management). A first focus is on the mathematical models of integrated and quasi-integrated 3D adjustment, which are associated with the joint parameterization of sensor data in the geometry and gravity space in the Gauß-Markov model (GMM). Integrated and quasi-integrated 3D adjustment prove to be the key models for the parametric integration of all sensor data types in geometry and gravity (gravimetry, GNSS, total stations, leveling, laser scanners, algorithmically adapted navigation sensors, optical sensor data up to SAR / INSAR). The section on integrated 3D geomonitoring (also called "system analysis", "structural health monitoring (SHM)") focuses on finite element models (FEM) for the common parameterization of physical and geometrical parameters. FEM is the key to answer the question of whether a monitoring object is in a "healthy" state or in a physical "unhealthy" state, classified as dangerous. For building vibrations (bridges, towers) they lead to inverse eigenvalue / vector problems, i. e. the task of concluding from changes in the spectral properties of the general eigenvalue problem to changes in the physical state.

The Stuttgart TV Tower is reference object for the above mentioned innovative methods for the early detection of hazard potentials of structures (SHM) by new algorithms, sensor systems and information technologies presented. The latter point includes a general Internet-based server client for integrated geo monitoring of objects.

Practical realization is based on the following mathematical algorithms. The integrated 3D Gauss-Markov model (GMM) with the functional model and the stochastic model $\mathrm{C}_{1}$ of observations 1 , with $l=l(x, z, W(x, p, c))(1)$ can be defined in the geodetic network adjustment as a so-called fixed boundary value problem. That means, within the proportion of the gravitational potential $\mathrm{W}$ 


$$
W(x, p, c)=V\left(p \mid r(x, y, z), \lambda^{\prime}\left(x, y, z \cdot \lambda_{0}, \theta_{0}\right)\right)+\frac{1}{2} \omega_{E}^{2} \cdot\left(x^{2}+y^{2}\right)
$$

the geocentric 3D position $x^{T}=(x, y, z)$ is not a free unknown. The vector $\mathrm{c}$ denotes the fixed parameters of the earth mass $M$, the gravitational constant $G$, the major semi-axis a of the reference ellipsoid, the angular velocity of the earth rotation and the position of the pole of the gravitational potential $\mathrm{V}$ in the gravitational potential $\mathrm{W}$ composed of gravitational potential $\mathrm{V}$ and centrifugal potential $\mathrm{Z}$. By the spherical cap representation (Adjusted Spherical Cap Harmonic (ASCH)) of the gravitational potential $\mathrm{V}$ the pole $\lambda_{0}, \theta_{0}$ mentioned above centrally located in the relevant region, and the associated generalized Legendre function, can be obtained with a spherical cap with far fewer SCHA parameters $\mathrm{p}$, as in the case of the global harmonic standard model $(\mathrm{SH})$ achieve high regional resolutions of the gravitational potential V. In addition, global spherical function models can be mapped into regional ASCH coefficients and introduced in the GMM of the W-based integrated 3D adjustment and used there as direct observations $p=\left(C_{n(k), m}^{\prime}, S_{n(k), m}^{\prime}\right)(3)$. In geomonitoring, however, the strict integrated 3D model will only be used, if observed gravity observations occur. For example, in case of large mass changes (mining, oil fields) or geodynamic networks. Otherwise, the simpler quasi-integrated 3D model can be used.

In quasi-integrated case, observations 1 of the GMM are parameterized reading

$$
\begin{aligned}
\bar{p}(W(x, p, c)) & =:(\varphi(x, p, c), \lambda(x, p, c), N(x, p, c)) \text { and } l \\
& =l(x, z, \bar{p}(W(x, p, c))), C_{l}
\end{aligned}
$$

The "geometrical" substitution parameters (4a) related to the gravitational field $\mathrm{W}$, are its "horizontal" component (astronomical directions $\varphi(x, p, c)$ and $\lambda(x, p, c)$ ) and its "vertical" component, the quasigeoid height $\mathrm{N}(\mathbf{x}, \mathbf{p}, \mathbf{c})$. For these it holds:

$$
\varphi(W(x, p, c))=\arctan \left(\frac{W_{z}}{\sqrt{W_{x}^{2}+W_{y}^{2}}}\right), \lambda(W(x, p, c))=\arctan \left(\frac{W_{y}}{W_{x}}\right), N(W(x, p, c))=
$$

$\mathrm{U}$ is the reference gravitational field (GRS80) and $\mathrm{\gamma}$ is the associated reference gravity value in the telluride point (height h-N). The geometrical parameters of the quasi-integrated 3D model related to the gravitational field are introduced pointwise as unknowns, and at the same time as direct observations of the GMM of the quasi-integrated $3 \mathrm{D}$ equations. For the relevant observation vector for TPS observations (horizontal directions, zenith angles and slope distances), the following equation holds:

$$
l_{i j}^{i}=\left[\begin{array}{c}
\Delta u \\
\Delta w \\
\Delta w
\end{array}\right]_{i j}^{i}=R_{e}^{i}\left(\varphi_{i}, \lambda_{i}\right) \cdot\left[\begin{array}{l}
\Delta x \\
\Delta y \\
\Delta z
\end{array}\right]_{i j}-\left[\begin{array}{l}
0 \\
0 \\
i
\end{array}\right]^{i}+R_{e}^{i}\left(\varphi_{i}, \lambda_{i}\right) \cdot R_{j}^{e}\left(\varphi_{j}, \lambda_{j}\right) \cdot\left[\begin{array}{l}
0 \\
0 \\
t
\end{array}\right]
$$


Based on (6), the following observation equations for slope distances, horizontal directions and zenith angles in the quasi-integrated $3 \mathrm{D}$ model are obtained:

$$
\begin{gathered}
s_{i j}=\sqrt{\Delta u_{i j}^{2}+\Delta v_{i j}^{2}+w_{i j}^{2}} \quad r_{i j}=\arctan \left(\frac{\Delta v_{i j}}{\Delta u_{i j}}\right)-0 \quad z_{i j} \\
=\arctan \left(\frac{\sqrt{\Delta u_{i j}^{2}+\Delta v_{i j}^{2}}}{\Delta w_{i j}}\right)-\frac{s_{i j}}{2 R} k
\end{gathered}
$$

By inserting the components of the abovementioned basic equation (6) in the observation equations (7), the relevant non-linear functional GMMs of the TPS observations by the global pointwise unknowns in the $3 \mathrm{D}$ geometry and gravity space of the network can be finally parametrized. Already direct in the earth-fixed geocentric-cartesian coordinate system ( $x, y, z)$, we have the functional GMM of 3D GNSS baseline observations b. These, and levelling observations 1 can be parameterized in the quasi-integrated $3 \mathrm{D}$ model as follows:

$$
\begin{gathered}
b^{T}=\left(\Delta x_{i j}, \Delta y_{i j}, \Delta z_{i j}\right) \\
\Delta H_{i j}=\left(h(x, y, z)_{j}-N_{j}\right)-\left(h(x, y, z)_{i}-N_{i}\right)
\end{gathered}
$$

In addition to the above mentioned TPS, GNSS and leveling observations the integrated and quasi-integrated 3D adjustment are also mandatory for the sensor and observation components

- Pixels of video tachymeters

- Laser scanner point clouds

- Terrestrial SAR as well as satellite-based INSAR and

- $\quad$ GNSS / MEMS sensor for Structural Health Monitoring (SHM)

Therefore, the integrated and quasi-integrated 3D adjustment are the sustainable key models of modern multisensorial 3D Geo and Structural Health Monitoring (SHM).

After the above mentioned successful tests, which have been started in 201516 , the R\&D project “The Stuttgart TV tower" as a reference object for the R\&D and testing of innovative sensor systems, mathematical models, algorithms, software and IT for the early detection of damage and potential risks of construction facilities (SHM)" with new IT infrastructures, was launched in 2017. At Karlsruhe university of Applied Sciences, the respective R\&D is carried out in the frame of the projects GOCA [1] and NAVKA [2] in the laboratory of Navigation \& GNSS. In addition, the engineering office for Applied Geodesy, Photogrammetry and Geoinformatics E. Messmer, Schwaikheim, and the SWR Baden-Württemberg, as the owner of the TV tower, and the state office for geoinformation and land development (LGL) in Karlsruhe as service provider for spatial reference via SAPOS GNSS corrections and the Baden-Württemberg IT service provider LF.NET are partners in the research project. 
Based on this cooperation the new IT infrastructure in order to support the continuous online monitoring of the tower's condition changes has been set up. Fig. 1 represents the common IT design. The whole procedure of data collection and processing covers several main steps:

1. Computation of exact object's position based on the raw GNSS data.

2. Data collection based on the fixed solution in respect to the object point positioning.

3. Creation of GKA interface with accurately precomputed object coordinates.

4. Visualization of time series for TV tower's rotations in deformation analysis software GOCA.

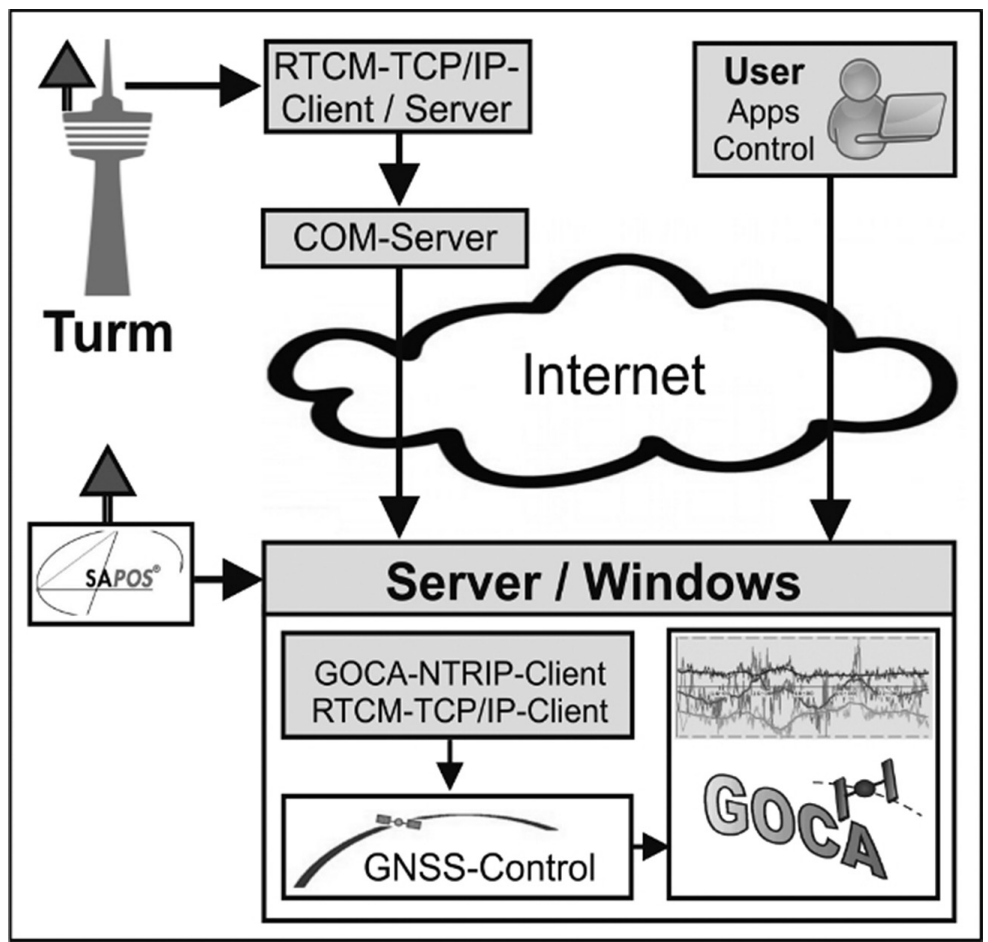

Fig. 1. Common network design for continuous geo monitoring purposes in project "Stuttgart TV tower"

On the server of LF.NET the continuous data is processed in $\mathrm{Hz}$ data frequency using the software GOCA and GOCA GNSS Control (fig. 1). The external access to the server with preinstalled and configured software is implemented via protected VPN connection. The visualization of the time series in deformation analysis software GOCA allows to control the adjusted GNSS data and to follow the 
vibration movements of the tower. Fig. 2 represents the results of 1 hour processed (so-called FIN) data.

In the integration of GNSS data with the data of MEMS and optical sensors (accelerometers, gyroscopes, cameras) as well as in the multi-sensor navigation in geomonitoring a total of 15 state parameters $\mathrm{y}(\mathrm{t})$ are to be modeled in the state estimation. The state vector $\mathrm{y}(\mathrm{t})$ reads:

$$
y(t)=\left[x^{e} y^{e} z^{e}\left|v_{x}^{e} v_{y}^{e} v_{z}^{e}\right| r^{e} p^{e} y^{e}|| \ddot{x}^{e} \ddot{y}^{e} \ddot{z}^{e} \mid \omega_{e b, x}^{b} \omega_{e b, y}^{b} \omega_{e b, z}^{b}\right]^{T}
$$

Compared to a usual standard navigation of moving objects in this case - via the introduction of inequalities to the state space $y(t)$ and a robust SIMPLEXbased L1 standard parameter estimation - the data fusion can be essentially stabilized in the geomonitoring case. The sensory scanning of objects in a dynamic state, using the FEM-based vibrational equations we have:

$$
\begin{aligned}
& K\left(p_{K}\right) \cdot u(t)+C\left(p_{C}\right) \cdot \dot{u}(t)+M\left(p_{M}\right) \cdot \ddot{u}(t)=f(t) \\
& K\left(p_{K}\right) \cdot u(t)+C\left(p_{C}\right) \cdot \dot{u}(t)+M\left(p_{M}\right) \cdot \ddot{u}(t)=0
\end{aligned}
$$

In Structural Health Monitoring (SHM) the above dynamic FEM-based equations - (10) forced damped vibration, (11) free damped eigen-vibration of a structure - allow to parametrize all physical parameters within the stiffness matrix $\mathrm{K}$, the damping matrix $\mathrm{C}$ and the mass matrix $\mathrm{M}$, while in the static case of a SHM only the stiffness matrix $\mathrm{K}$ of a structure is accessible. In the case of abovementioned eigen-vibration (11) we get in the time domain the basic equation for the SHM modeling as [3]:

$\left[\begin{array}{l}u_{O}(t+\Delta t) \\ \dot{u}_{O}(t+\Delta t) \\ \ddot{u}_{O}(t+\Delta t)\end{array}\right]=\left[\begin{array}{ccc}I & {[\Delta t]} & {\left[\frac{1}{2} \Delta t^{2}\right.} \\ 0 & I & {[\Delta t]} \\ 0 & {\left[-M\left(p_{M}\right)^{-1} \cdot K\left(p_{K}\right) \cdot \Delta t\right]} & {\left[I-M\left(p_{M}\right)^{-1} \cdot C\left(p_{C}\right) \cdot \Delta t\right]}\end{array}\right] \cdot\left[\begin{array}{l}u_{O}(k) \\ \dot{u}_{O}(k) \\ \ddot{u}_{O}(k)\end{array}\right]($

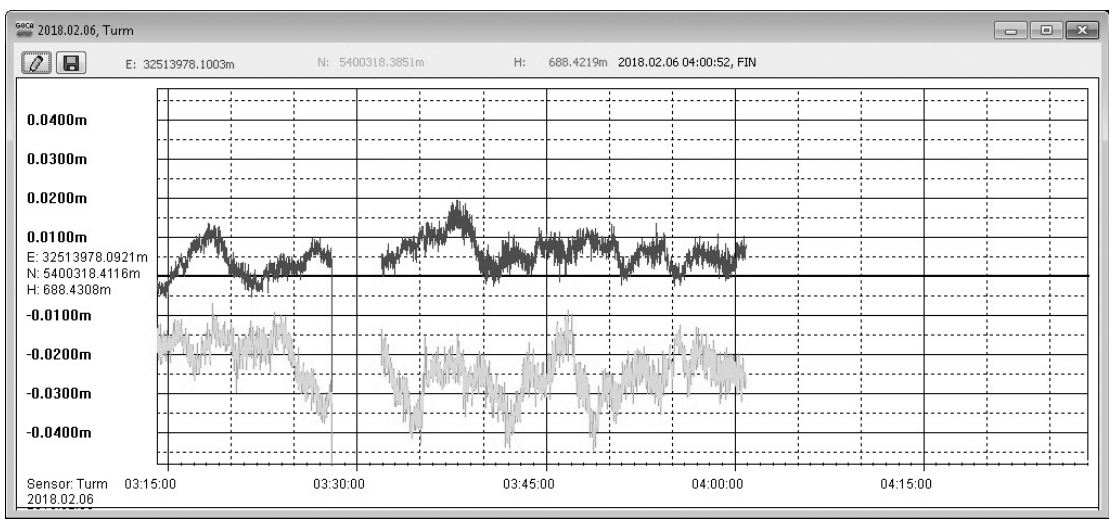

Fig. 2. Visualization of time series in project "Stuttgart TV tower" using deformation analysis software GOCA 
The equation (12) gives the relation between the displacements $\mathrm{u}_{\mathrm{o}}(\mathrm{t})$, their derivatives in time, and the parameterized matrices $(\mathrm{K}, \mathrm{C}, \mathrm{M})$ as the starting relation of the state estimation in SHM. In the spectral domain, we obtain by parameterizing the changes in the physical parameters as a function of changes in the spectral and modal matrix, again in the case of a (now undamped) structural eigen-vibration [3]:

$$
\Delta \omega_{i}^{2}\left(\Delta p_{K}, \Delta p_{M}\right)=u_{i}^{T} \cdot\left[d K\left(\Delta p_{K}\right)-\omega_{i}^{2} \cdot d M\left(\Delta p_{M}\right)\right] \cdot u_{j}
$$

$\Delta u_{i}\left(\Delta p_{K}, \Delta p_{M}\right)=-\frac{u_{i}^{T} \cdot d M\left(\Delta p_{M}\right) \cdot u_{i}}{2} \cdot u_{i}+\sum_{\substack{j=1 \\ j \neq i}}^{n}\left[\frac{1}{\omega_{i}^{2}-\omega_{j}^{2}} u_{i}^{T} \cdot\left[d K\left(\Delta p_{K}\right)-d M\left(\Delta p_{M}\right)\right] \cdot u_{j}\right] \cdot u_{j}$

Equation (14) is to be regarded as initial relation for the solution of the respective so-called inverse eigenvalue problem, that allows to conclude from changes in the above-mentioned eigen-vibration characteristics (spectral and modal matrix) on the changes of the structural health state in geomonitoring.

\section{REFERENCES:}

1. R. Jäger (1998-2018): GOCA-Website. www.goca.info

2. R. Jäger (2010-2018): NAVKA-Website. www.navka.de

3. Jäger, R., Gorokhova, L. und E. Messmer (2017): Modell- und Sensorintegration zum integrierten 3D Geomonitoring in moderner Daten, kommunikationsstruktur mit Anwendung auf den Stuttgarter Fernsehturm. Ingenieurvermessung 17: Beiträge zum 18. Internationalen Ingenieurvermessungskurs Graz, 2017. Wichmann-Verlag. ISBN: 978-3-87907-630-7. S.23-251. 


\title{
ATVĒRTĀ KODA LIDAR SISTËMAS IZVEIDE SPELEOLOG̣ISKIEM PËTİJUMIEM
}

\author{
J. Ješkins, J. Karušs, V. Zandersons \\ LU G̣eogrāfijas un Zemes zinātṇu fakultāte \\ E-pasts: jurijs.jeshkins@gmail.com
}

LiDAR (Light Detection And Ranging) ir salīdzinoši jauna tehnoloǵija, kas l̦auj iegūt precīzus datus par skenētās virsmas reljefu un relatīvu novietojumu pret sensoru. Galvenokārt, LiDAR tehnologiju pielieto Zemes virsmas reljefa model̦a iegūšanai (piem. Ma, 2005; Liu, 2008). Bet, pateicoties plašai pieejamībai, LiDAR var izmantot arī citās nozarēs.

Veicot speleoloǵiskus pētījumus, jāsaskaras ar apgrūtinošu datu iegūšanas procesu. Alu kartēšanas uzdevumu risināšanā darbojas citi principi, nekā ierastajā kartēšanā. Mūsdienās pielietojamās tehnologijas, tādas kā GPS, nav pieejamas pazemes izpētes vietās, tāpēc pētnieki ir spiesti pielāgoties jauniem apstākliem. Pielietojot LiDAR tehnologijas alās, kartēšanas uzdevumi tiek efektīvi risināti (Zlot un Bosse, 2012). Kā arī, vienlaikus ar kartes sastādīšanu tiek iegūts viens no vizuāli uzskatāmākiem alu attēlošanas veidiem - 3D modelis. Tirgū ir pieejams plašs klāsts ar 3D skenēšanas ierīcēm, lielāka daḷa no kuriem ir l̦oti dārgas iekārtas, kas nav domātas darbam apstākḷos, kuros iekārta var saṇemt spēcīgus mehāniskus triecienus vai nonākt lielā mitrumā. Skenēšanas tehnologijas attīstās ātros tempos un katru gadu ir pieejamas jaunas ierīces. Pateicoties tādai ātrai attīstībai, tehnologijas kḷūst pieejamas arī plašai auditorijai. Kompānija Garmin ir viens no tādiem ražotājiem, kas ir izstrādājis plaši pielietojamo sensoru Garmin Lidar Lite (Garmin, 2016). Šobrīd ir pieejama jau trešā sensora versija. Savā attīstības gaitā, sensoram ir uzlabojusies precizitāte, skenēšanas ātrums, kā arī savietojamība ar citām ierīcēm.

Latvijas Universitātē tiek izstrādāts jauns inovatīvs instruments, kas palīdzēs veikt 3D skenēšanas darbus. Ierīce sastāv no 3 daḷām: 1) LiDAR sensors, 2) kustīga platforma sensora novietošanai pret objektu, 3) Arduino mikroprocesors, kas kontrolē instrumenta darbību. Izstrādāta tehnologiija ir bāzēta uz atvērta koda tipa sastāvdal̦ām. Tas l̦auj ērti modificēt un attīstīt ierīci, pielāgojot to dažādu uzdevumu risināšanai.

Lai pārbaudìt ierīces darbību, tika veikts pētījums Inčukalna Velnalā. Lauka darbu gaitā tika veikti 7 skenējumi dažādās alas vietās. Iegūtie dati tika apstrādāti un trīs skenējumi tika apvienoti lai izveidot 3D modeli (skat. 1. attēlu). Rezultātā, izveidotais 3D modelis l̦auj noteikt alas morfometriskus radītājus un aprēḳināt tilpumu. 
Turpinot ierīces attīstību, tiek plānots uzlabot mitruma drošību, lai pielāgotu to glaciologiskiem pētijumiem.

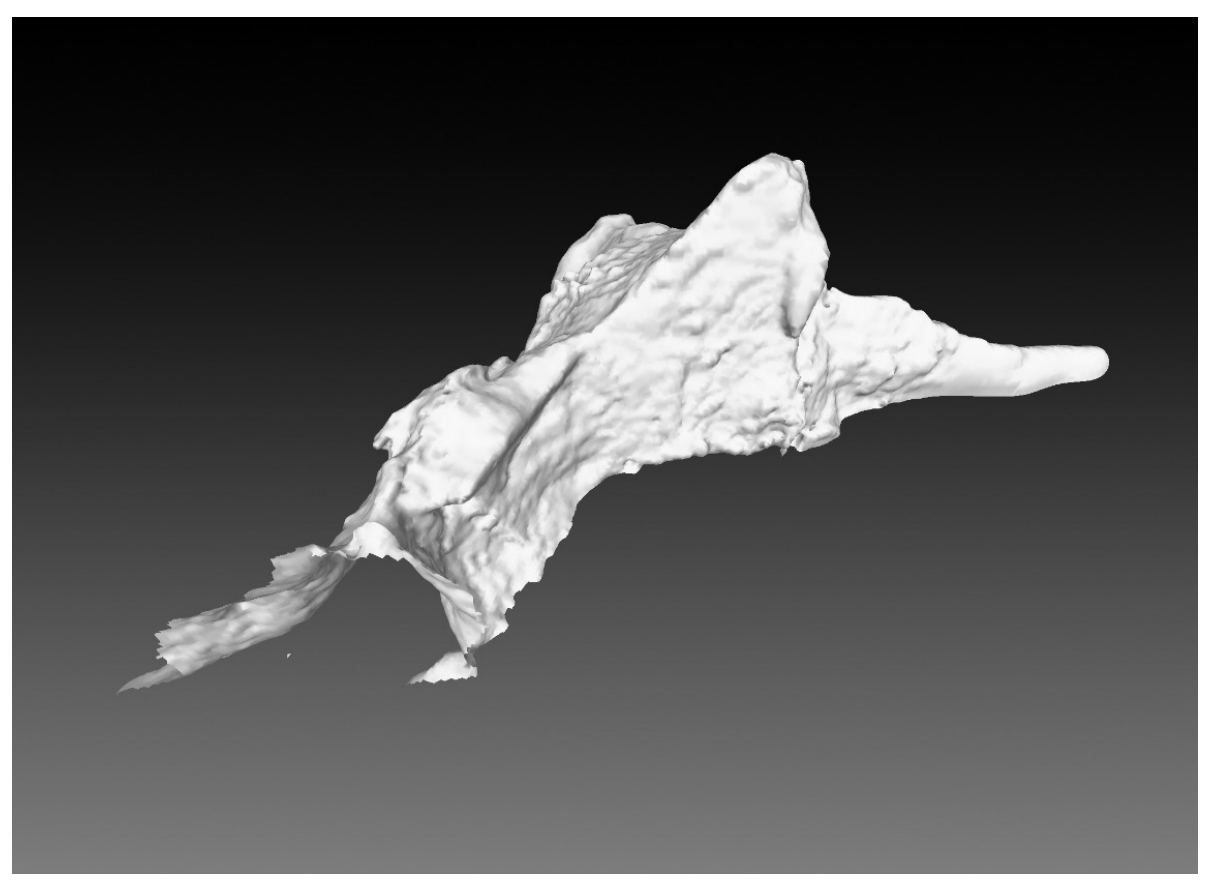

1. attēls. Inčukalna alas 3D modelis

\section{LITERATŪRA:}

1. Garmin, 2016. Lidar Lite v3 Operation Manual and Technical Specifications. Garmin Ltd.

2. Liu X., 2008. Airborne LiDAR for DEM generation: some critical issues. Progress in Physical Geography. v.3, is.1., p. 31-49.

3. Ma R.,2002.DEM Generation and Building Detection from Lidar Data. Photogrammetric Engineering \& Remote Sensing.

4. Zlot R., Bosse M., 2012. Three-Dimensional mobile mapping of caves. Journal of Cave and Karst studies, v.76, no.3, p. 191-206. 


\title{
ANALYSIS OF DETERMINATION METHODS OF DYNAMIC OBJECT MOTION PARAMETERS
}

\author{
A. Kluga, J. Kluga ${ }^{1}$ \\ ${ }^{1}$ Riga Technical University, Faculty of Electronics and Telecommunications \\ E-mail: ansis.kluga@inbox.Iv
}

Dynamic objects are used in many fields where navigation, attitude, heading and height determination are necessary. Motion parameters are 3D position, 3D velocity vector, $3 \mathrm{D}$ acceleration and full 360 degrees $3 \mathrm{D}$ orientation (Attitude and Heading). All applications for parameter determinations used Global Navigation Satellite System (GNSS) as base system. In our days GPS, GLONASS, GALILEO and BeiDou or Compass satellite systems are used.

Precision of mobile object position measurements is a function of many factors. Practically all receivers can be classified as low cost $(<200 \$)$ and high cost devices $(>200 \$)$. All measurements are realized with loop filters. The objective of the loop filter is to reduce noise in order to produce an accurate estimate of the original signal at its output. The loop filter order and noise bandwidth also determine the loop filter's response to signal dynamics (Kaplan et al. 2006). The loop filter's output signal is effectively subtracted from the original signal to produce an error signal, which is fed back into the filter's input in a closed loop process. The number of integrators completely determines the loop filter's characteristics. The analog loop filters may be first, second, and third-order analog filters. There are many design approaches to digital filters. Random mean square error (RMSE) of distance (D) measurement with loop system can be calculated as (Eq. 1):

$$
\sigma_{\Delta D}=\frac{\tau \cdot c}{\left(z \cdot \sqrt{\frac{\Delta f_{s}}{\Delta F_{L}}}\right.}
$$

Where: $\tau$ - signal pulse length, $\mathrm{z}$ - signal to noise power ratio, $\Delta \mathrm{f}_{\mathrm{s}}$ and $\Delta \mathrm{F}_{\mathrm{L}}$ signal and noise bandwidth.

Calculation RMSE for standard GPS system $\left(\tau=1 \mu\right.$ s, $\mathrm{z}=1$ and $\left.\Delta \mathrm{F}_{\mathrm{L}}=10 \mathrm{~Hz}\right)$ give $\sigma_{\Delta \mathrm{D}}=1 \mathrm{~m}$.

RMSE can be reduced, if loop systems bandwidth is decreased (Eq. 1), but this will affect dynamical properties of GPS system. Histogram of measurement error probability distribution (Figure 1) shows Gaussian distribution for noise error. 


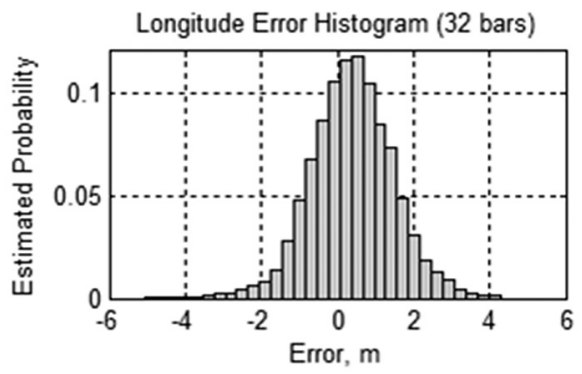

Fig.1. Longitude error histogram for Graymark GPS-101 receiver latitude over 24 hours

Dynamical parameters of satellite measurement system are dependent on number of integrators and loop systems bandwidth (Golnaraghi et al. 2010). System with one integrator has constant error if parameter changes with constant velocity. In our case if velocity of distance change is $\mathrm{V}_{\mathrm{D}}$, error will be $\mathrm{V}_{\mathrm{D}} / \Delta \mathrm{F}_{\mathrm{L}}$. For system with two integrators value of error is $a_{D} / \Delta F_{L}$, where $a_{D}$ is acceleration. For three integrators error will be only short time of acceleration change. This is important for loop system to choose bandwidth value. For different mobile object types there are optimal value of bandwidth.

For frequency measurements also loop filters with integrators are used. Frequency measurements have all receivers, because they are necessary for satellite data obtaining, but not all of them have velocity output.

Phase measuring determines phase of receive signals of satellites. These measurements are realized after code tracking is done. For error reducing signals of land correction stations are used. There are two methods of correction: post processing and real time kinematic (RTK). First is used for precision geodesic works, second for mobile objects. For phase measurements also loop filters with integrators are used. Ours experimental results in static mode with GRS-1 receiver (Belinska et al. 2014) show that centimeter accuracy is designed, and error distribution have the normal (Gaussian) distribution.

For solving the problem of precision determination in dynamic mode, when car ride with high velocity we used two receivers. Antennas of receivers were located on constant distance, measured with high precision (one millimeter). Using data of two GPS receivers with phase measurement and RTK we calculate distance between two antennas and then precision was calculated.

High-precision phase system satellite receivers with real-time data correction can be used for dynamic object location and motion parameters determination up to speed $100-110 \mathrm{~km} / \mathrm{h}$. To ensure uninterrupted determination of mobile object location in poor visibility conditions, it's required to use additional inertial sensors and simplest complex signal processing with a data comparison and filtration. 
GPS and micro-electro-mechanical (MEMS) inertial systems have complementary qualities that make integrated navigation systems more robust. The effective integration of GPS and MEMS sensors is still challenging task for navigation system. Kalman filters are widely used for sensor data fusion and navigation in mobile devices. Taking in account GPS and inertial data processing problem nonlinearity, the Extended Kalman Filter (EKF) is widely used. One of the most important tasks in integration of GPS/INS is to choose the realistic dynamic model covariance matrix $\mathrm{Q}$ and measurement noise covariance matrix $\mathrm{R}$ for use in the Kalman filter. Adaptive algorithms automatically adjust Kalman filter system and measurement noise covariance matrix parameters taking in account navigation process performance i.e. position error.

\section{REFERENCES:}

1. Kaplan E., Hegarty C. Understanding GPS: principles and applications $-2^{\text {nd }} e d .2006$, ARTECH HOUSE, INC.

2. Golnaraghi F, Kuo B. C. Automatic Control Systems. 9 edition, J. Wiley \& Sons, inc. 2010, $786 \mathrm{pp}$.

3. Belinska V, Kluga A, Klūga J, Bricis A. Accuracy Estimation of TOPCON GRS-1 GNSS Receiver Parameters in Static and Dynamic Mode. Electronics and Electrical Engineering, 2014, Vol.20, No.2, 89.-92.lpp. ISSN 1392-1215. e-ISSN 2029-5731. 


\title{
AUGSTAS DETALIZĀCIJAS G̦EOTELPISKĀS INFORMĀCIJAS PROBLĒMJAUTĀJUMI
}

\author{
U. Krutova ${ }^{1,2}$ \\ ${ }^{1}$ Rīgas Tehniskā Universitāte \\ ${ }^{2}$ Mērniecības Datu Centrs \\ E-mail: una.krutova@mdc.Iv
}

Absolūti atbilstoša realitātei ir tikai pati realitāte. Tas nozīmē, ka perfekts apvidus modelis būtu izgatavojams mērogā 1:1. Praksē, protams, šādas detalizācijas ǵeotelpiskā informācija netiek un visticamāk arī nekad netiks uzkrāta.

Visdetālākā geotelpiskā informācija, kas kopš 2012.gada sistemātiski tiek uzkrāta un, atbilstoši G̣eotelpiskās informācijas likumam ir valsts ǵeotelpiskās informācijas pamatdati, ir augstas detalizācijas topogrāfiskā informācija mērogā 1:500.

N̦emot vērā, ka šì augstas detalizācijas topogrāfiskā informācija ir visdetālākie valsts rīcībā esošie geotelpiskie dati, šìs informācijas ieguvi regulē speciāli normatīvie akti. Atbilstoši šiem normatīvajiem aktiem, iegūtā augstas detalizācijas topogrāfiskā informācija tiek glabāta vienotā datubāzē un veicot attiecīgās teritorijas atkārtotu uzmērī̌šnu, apvidū skaidri izteiktiem objektiem un situācijas kontūrām noteikto koordinātu un augstumu starpība nedrīkst pārsniegt 5 centimetrus koordinātām un 3 centimetrus augstumam.

Lai gan augstas detalizācijas topogrāfiskā informācija noteikti ir visprecīzākā pieejamā geotelpiskā informācija, tomēr, izmantojot šo informāciju, jārēḳinās ar tās ieguves un uzturēšanas īpatnībām.

Augstas detalizācijas topogrāfiskās informācijas datubāze nav datubāze geootelpisko informācijas sistēmu izpratnē. Faktiski tās ir noteiktā sistēmā sakārtotas 281824 karšu lapas, kas satur topolog̣iski nesakārtotus datus. Ar informāciju aizpildìts ir $21 \%$ no šìm karšu lapām. Labā ziṇa ir tāda, ka eksistē reglamentēta elementu attēlošanas specifikācija, tāpēc jebkurā karšu lapā viena un tā paša veida apvidus objektam būtu jābūt attēlotam vienādi. Veicot 38000 karšu lapu datu importu vienkāršu geeometriju datu bāzē, nācās konstatēt, ka 16\% datu (29 647270 elementu) neatbilst definētajām specifikācijas prasībām.

Otra problēma, kas traucē veidot strukturētu informāciju ir datu mozaīkveida raksturs. Kartes lapā tiek ievietots atsevišķs topogrāfiskais vai izpildmērījuma plāns, kas neveido vienlaidus teritorijas pārklājumu. Tādejādi nav iespējams iegūt visaptverošu informāciju, piemēram par ūdensvada izvietojumu kādā administratīvajā teritorijā.

Valsts geodēziskās atskaites sistēmas realizāciju apvidū nodrošina valsts geeodēziskais tīkls, ieskaitot pastāvīgo globālās pozicionēšanas bāzes staciju sistēmu "Latvijas Pozicionēšanas sistēma" (LatPOS). Jāatzīst, ka augstas detalizācijas 
informācijas iegūšanai izmantojamais geodēziskā atbalsta tîkls nav pietiekams, lai nodrošinātu normatīviem atbilstošu punkta noteikšanas precizitāti. Bažas raisa 2017. gadā veiktā Latvijas Ģeotelpiskās informācijas ağentūras veiktā aptauja, kuras rezultāti parāda, ka tikai 18 no 119 Latvijas pašvaldībām ir pieņēmušas lēmumu par vietējā geodēziskā tīkla pilnveidošanu. Tikai 8 pašvaldības gatavojas vietējo geodēzisko tīklu pilnveidot sistemātiski. Prakse rāda, ka topogrāfiskie uzmērijjumi visbiežāk tiek veikti reālā laika režìmā, bez piesaistes punktiem ar zināmām koordinātām un augstumiem.

Papildus drauds topogrāfisko plāna informācijas precizitātes uzticamībai ir fakts, ka datiem vienā un tajā pašā topogrāfiskajā plānā mēdz būt ḷoti dažāda izcelsme - ir dati, kas iegūti dažādu mērỉjumu cel̦ā, ir dati, kas pārzīmēti no papīra no planšetēm, bet dažreiz šì informācija ir iegūta no "zinošas personas" nostāstiem. Jo īpaši dati par apakšzemes komunikācijām ne vienmēr iegūti uzmērijjumos.

Raugoties uz augstas detalizācijas topogrāfisko informāciju no datu atkalizmantošanas perspektīvas, būtu jāpievērš pastiprināta uzmanība datu precizitātes, izcelsmes, topologiskās sakārtotības un homogenitātes jautājumiem. Nepieciešams atdalìt mainīgo un nemainīgo datu segmentu un apsvērt nemainīgo, īpaši tīklveida apakšzemes struktūras attēlojošo, datu uzturēšanu pilnvērtīgās un analizējamās ğeogrāfiskās informācijas sistēmās. 


\title{
IMPORVEMENT OF Ogeoid OF LATVIA
}

\author{
K. Morozova ${ }^{1,2}$ \\ ${ }^{1}$ University of Latvia, Institute of Geodesy and Geoinformatics \\ ${ }^{2}$ Riga Technical University, Faculty of Building and Civil Engineering, \\ Department of Geomatics \\ E-mail: katerina.morozova@lu.Iv
}

In terms of "Development of the high accuracy gravity field model for Latvia including sea territory" agreement Nr.1.1.1.1/16/A/160 project the main task is to compute precise gravity field and quasi-geoid model up to $1 \mathrm{~cm}$ accuracy using all available data.

In the year of 2016 quasi-geoid model for Eastern part of Latvia has been computed using Karlsruhe University of Applied Sciences developed DFHRS (Digital finite-Element Height Reference Surface) software v.4.2. (Jäger 2000-2017), which allowed the combination of GNSS/levelling data together with global geopotential models (e.g. EGM2008 (Pavlis 2008), EGG97 (H. Denker \&W. Torge 1997)). But some inconsistencies were found by comparing the use of different geopotential models as input data.

At the moment Institute of Geodesy and Geoinformatics (GGI) is dealing with new kind of measurements - vertical deflections' observations - which are possible to use in DFHRS v.4.3. Updated version of DFHRS allows to use GNSS/ levelling data together with geopotential models and field vertical deflections measurements or/and vertical deflections derivatives from geopotential models. Vertical deflections measurements allow to check independently the places that have inconsistencies and improve qgeoid model. Digital-zenith camera is used for this purposes. Test measurements were done in Riga region and proved the improvement of qgeoid twice (Morozova et al. 2017). Digital-Zenith camera and processing software was developed by GGI (Zarins et al. 2016) and these observations are actively done in Kurzeme region now. The current amount of points is equal to 32 and the precision of these measurements is $0,10-0,15$ arcsec. In terms of a project, $46 \mathrm{GNSS}$ points were observed in western region of Latvia by GGI, but 2 points were excluded at once after GNSS data post processing, because of high RMS in Bernese GNSS Software v.5.2, and 2 points were excluded because of gross error in DFHRS software. $1^{\text {st }}$ and $2^{\text {nd }}$ order levelling data and 147 GNSS points were provided by Latvian Geospatial Information Agency.

At the $1^{\text {st }}$ stage of development the total amount of GNSS/levelling points is equal to 352 and 68 field vertical deflections measurements (Fig.1). The distance between GNSS/levelling points is about $10-15 \mathrm{~km}$ in order to provide sufficient data coverage and to reach $1 \mathrm{~cm}$ precision qgeoid model for Latvia. Vertical deflections 
measurements are to be continued in order to cover homogeny the whole territory and improve current version of qgeoid (Fig.2).

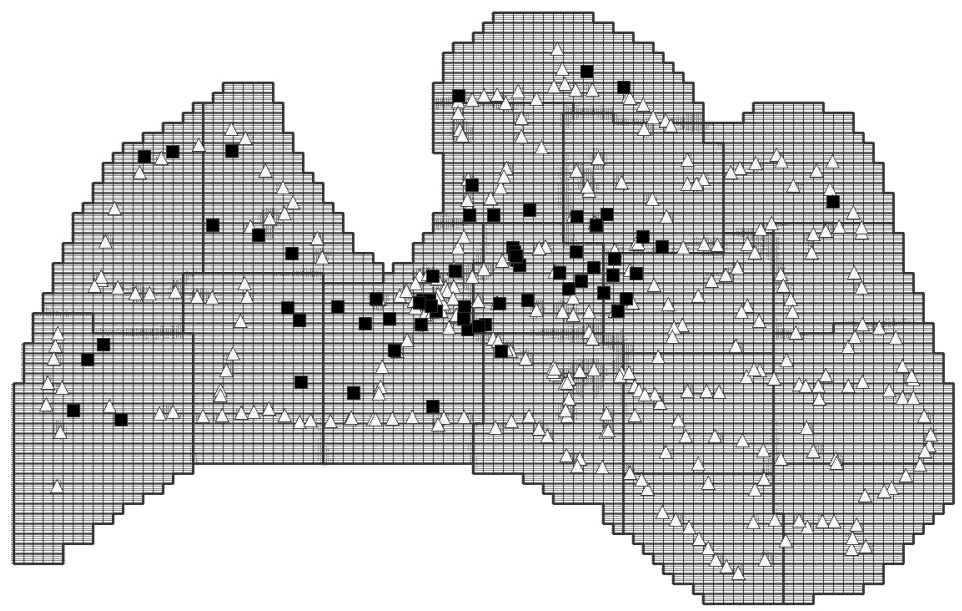

Fig. 1. The design of a model for Latvia (green triangles - GNSS/levelling points, black square - vertical deflections' measurements)

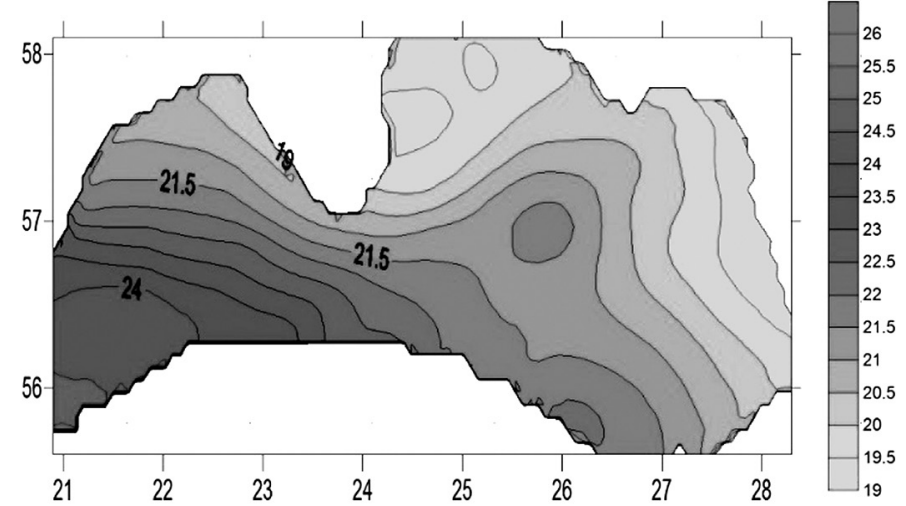

Fig. 2. Current version of qgeoid of Latvia (combined model of Western part together with Eastern one).

Acknowledgment:

The research was developed under the contract ERAF Nr. 1.1.1.1/16/A/160. With the best thanks of the author to the dr. phys. Ansis Zarins, dr. sc. ing. Gunars Silabriedis and Kriss Balodis for providing Digital Zenith camera's observations and Latvian Geospatial Information Agency for the $1^{\text {st }}$ and $2^{\text {nd }}$ order levelling data and GNSS points. 


\section{REFERENCES:}

1. R. Jäger, (2000-2017): DFHBF-Website, www.dfhbf.de (accessed 29 January, 2018)

2. N. Pavlis (2008): Earth Gravitational Model EGM2008 http://earth-info.nga.mil/ GandG/wgs84/gravitymod/egm2008/ (accessed 29 January, 2018)

3. H. Denker \& W. Torge (1997) http://www.isgeoid.polimi.it/Geoid/Europe/europe_g. html 29.01.2018 (accessed 29 January, 2018)

4. K. Morozova, J. Balodis, R. Jäger, A. Zarins and A. Rubans Digital Zenith Camera's Results and Its Use in DFHRS v.4.3 Software for Quasi-Geoid Determination / (Technical Papers) // Baltic Geodetic Congress (Geomatics) (BGC Geomatics); Gdansk University of Technology, Poland, 22-25 June, 2017 : Proceedings P. 174178. DOI: 10.1109/BGC.Geomatics.2017.74., URL: http://ieeexplore.ieee.org/ document/8071467/ ISBN 9781509060412.

5. A. Zariņš, A. Rubans, and G. Silabriedis, "Digital zenith camera of the University of Latvia," Geodesy and Cartography, 42:4, 2016, pp. 129-135. http://dx.doi.org/10.3846/ 20296991.2016.1268434. 


\title{
SEISMOTECTONIC PREREQUISITES FOR THE GEODYNAMIC HAZARD OF LATVIA
}

\author{
V. Nikulins \\ University of Latvia, Faculty of Geography and Earth Sciences \\ E-mail:valerijs.nikulins@lu.Iv
}

The territory of Latvia is removed from the boundaries of tectonic plates and is located in the northwestern part of the ancient Precambrian East European Craton (EEC). The main tectonic stresses are due to pressure from the Mid-Atlantic Ridge, where the divergent zone is located. This zone has a complex, arcuate shape and extends from $39.5^{\circ} \mathrm{N}$ to $73.7^{\circ} \mathrm{N}$. The integral vector of the main horizontal tectonic stress at any point in the territory of Latvia is defined as the sum of the individual vectors and the local tectonic stress component . Local tectonic stress component depends on the geological structure of a particular territory, history and direction of geological development. Based on the solution of the mechanisms of the earthquake foci of Southern Sweden (Slunga et al. 1984), the azimuth is in the range $127.6^{\circ}-144.5^{\circ}$, and on the basis of the solution of the mechanisms of the Kaliningrad earthquake foci on September 21, 2004 (Gregersen et al. 2007) the azimuth varies from $156.9^{\circ}$ to $159.1^{\circ}$.

The direction of the horizontal velocity vector of moving the reference points of the GPS network is determined by the direction. The module is practically unchanged (about $24 \mathrm{~mm} /$ year), and the azimuth varies from $46.7^{\circ}$ to $60.5^{\circ}$, for GPS stations in the direction from the southwest to the northeast, from the Iberian Peninsula to Scandinavia. Obviously, changed during the geological history of development, which can be evidenced by different types of tectonic regimes for tectonic faults with close azimuths. On the territory of Latvia, the directions of tectonic faults in the crystalline basement and the Caledonian structural complex are oriented mainly in the direction south-west - north-east, i.e. close to the orientation for GPS Riga, equal to $56.5^{\circ}$. Tectonic regimes of most faults correspond to one of three closely related types: normal fault (throw) NF; prevailing normal fault with strike-slip component - NS; strike-slip fault, including a small normal component or thrust component SS. Only one tectonic fault (Olaine-Incukalns) and the longest $(\sim 133 \mathrm{~km})$, is defined as a fault of thrust type - TF (Brangulis et al. 1984; Brangulis \& Kanevs 2002) or the predominant thrust mechanism with a strike-slip component - TS. The difference in the tectonic regimes just indicates a significant change in or or a combination of them. It is the Olaine-Incukalns tectonic fault that causes increased attention over the past few years. A number of studies indicate the activation of the Olaine-Incukalns fault and tectonic zone formed by the Olaine-Incukalns and Bergu faults (Никулин 2011; Nikulins 2017). Particularly indicative in this respect is the radon anomaly, 
which is connected to the Olaine-Incukalns fault in the Sigulda area (Nikulins \& Gilucis 2018). It is known that radon anomalies are indicators of tectonic activity.

Since the geodynamic conditions are closely related not only to , but also to the deep geological structure, then deep seismic sounding - DSS along the SovetskRiga-Kohtla-Yarve profile (Ankudinov et al. 1988) and along the EUROBRIDGE profile in the neighboring territory of Lithuania (Bogdanova et al. 2006) was of great importance for understanding geodynamic conditions. The DSS made it possible to obtain seismic-geological parameters of the section, which made it possible to estimate the isostatic index, to compare it with geophysical, neotectonic, geodetic parameters and to obtain a model for geological processes in some areas of the East-Baltic region (Nikulin 1999). Non-random coincidence of maximum values of , neotectonic movements, heat flow is confirmed by the maximum of modern vertical movements in the area of Ieriki (+3.5 mm/year). Interpretation of these results made it possible to identify 5 sites of anomalous values of and to create a model for geological development. According to the model, there is an inversion relationship between the position of the Earth's surface and the Moho discontinuity for Ieriki area and neighborhoods. Here, the Earth's crust has an increased thickness $(58-59 \mathrm{~km})$, which is greater than the average thickness of the Earth's crust of East-Baltic region. The Moho boundary is deeper than necessary. Therefore, the rise of the Earth's surface in the area of Ieriki compensates for the deep processes of reconstruction of the Earth's crust. Identification of types of the Earth's crust allows foreseeing the trend of development of geodynamic processes, as well as seismotectonic activation.

An important object of geodynamic research is the Plavinas HPP as the largest hydroelectric station in the East-Baltic region. Much later of the creation of the Plavinas HPP, in 1981 - 1985, seismic surveys were carried out (Бебриш и др 1986). They made it possible to identify the Piebalga and Aizkraukle tectonic faults, which form a narrow $(3.7 \mathrm{~km})$ graben-like structure. At the south-western edge of the Piebalga fault is located the dam of the Plavinas HPP. Results of leveling and neotectonic studies conducted at the Plavinas geodynamic polygon in 19621970 made it possible to reveal the block structures of the crystalline basement and alternating, short-period movements of geodetic marks with periods of 5 to 6 years (Аболтыньш 1969; Аболтыньш 1971).

The results of the modeling of the Earth's crust motion in the area of the abovementioned tectonic structures showed that the dam of the Plavinas HPP and the head part of the Plavinas reservoir are located in the zone of depression, immersion (Nikulins 2015). The parameters of this depression depend on the direction and magnitude of the main tectonic stress accepted for calculations. Thus, the geodynamic situation in the area of the Plavinas reservoir cannot be considered satisfactory. Moreover, it is complicated by local destructive processes (suffosion). More research is needed, including increased density of geodetic 
reference points on the leveling profile, exploration of tectonic stresses in the well and in-situ, seismic monitoring and monitoring using remote methods GNSS (Global Navigation Satellite System) or PSI (Persistent Scatterer Interferometry). Despite the platform conditions in which Latvia is located, geodynamic studies are relevant from the point of view of scientific and practical significance.

\section{REFERENCES:}

1. Slunga R. \& Norrman P. Seismicity of southern Sweden (1984). FOA Report, C2 C 20543-T1, Stockholm, 106 pp.

2. Gregersen S., Wiejacz P., Debski W., Domanski B., Assinovskaya B., Guterh B., Mantyniemi P., Nikulin V. G., Pacesa A., Puura V., Aronov A. G., Aronova T. I., Grunthal G., Husebye E. S., Sliaupa S. The exceptional earthquakes in Kaliningrad district, Russia on September 21, 2004(2007). Physics of the Earth Plabetary Interiors $164,63-74$.

3. Никулин В. Г. Сейсмические сотрясения 22 ноября 2010 года в Риге и Рижском районе (2011). Актуальные вопросы мониторинга геологической среды и безопасности урбанизированных территорий. Тезисы докладов. БФУ им. Канта, Калининград, 49-52.

4. N̦ikuḷins V. Olaines-Inčukalna - Berǵu lūzumu zonas seismotektoniskās aktivitātes pazìmes (2017). Lietišķi ǵeologiiskie pētījumi. Tēžu krājums. 75. Latvijas Universitātes zinātniskā konference. 26-28 lpp.

5. N,ikulins V., Gilucis A. Radon anomalies as indicator of the geodynamic activity of the Olaine-Inčukalns fault (2018). Tēžu krājums. 76. Latvijas Universitātes zinātniskā konference (In the print).

6. Анкудинов С. А., Брио Х.С., Садов А.С. Глубинное строение земной коры на территории Прибалтики по данным сейсморазведочных работ ГСЗ (1991). Белорусский сейсмологический бюллетень, 1, 111-117.

7. Bogdanova S., Gorbatschev R., Grad M., Janik T., Guterh A., Kozlovskaya E., Motuza G., Skridlaite G., Starostenko V., Taran L. \& EUROBRIDGE and POLONAISE working groups. EUROBRIDGE: new insight into the geodynamic evolution of the East European Craton (2006). European Lithosphere Dynamics. Gee D.D. \& Stephenson R.A. (eds), Geological Society, London, Memoirs, 32, 5990625.

8. Nikulin V. Correlation between isostatic anomalies and neotectonic movements in Latvia (1999). Tehnika Poszukiwan Geologicznuch. Geosynoptyka i Geotermia. Krakow, 1 (195), 68-76.

9. Бебриш Э.В., Веремейчик Р.А., Кучеренко В.И. и др. Отчет о проведении поисковых работ для захоронения промстоков, не поддающихся очистке в Елгавском, Бауском, Стучкинском и Екабпилском районах за 1981-1985 гг. (1985). Oтчет. Valsts geologijas fonds.

10. Аболтыньш О.П. Современные движения в районе водохранилища Плявиньской ГЭС (1969). Отчет. Министерство геологии СССР. ВНИИ МОРГЕО. 107 стр.

11. Аболтыньш О.П. Изучение современных движений на опытном полигоне по данным повторного высокоточного нивелирования с целью подтверждения их колебательного характера (1971). Отчет. Министерство геологии СССР. ВНИИ МОРГЕО. 94 стр.

12. N̦ikuḷins V. Pḷaviṇu HES apkārtnes Zemes garozas geodinamisko apstākḷu izpēte (2015). Atskaite. Lìgums Nr. 01R000/15-17. 


\title{
SPACE WEATHER AND GNSS OBSERVATIONS
}

\author{
M. Normand ${ }^{1,2}$ \\ ${ }^{1}$ University of Latvia, Institute of Geodesy and Geoinformatics \\ ${ }^{2}$ Riga Technical University, Faculty of Building and Civil Engineering \\ E-mail: madaracaunite@yahoo.com
}

European Commissions' Community Research and Development Information Services' (CORDIS), Horizon 2020 projects on Space weather research programme COMPET-5-2017, focuses on the improvement of the understanding of Space Weather phenomena and their impact on space systems and terrestrial infrastructure and are also expected to analyze viable mitigation strategies, and to demonstrate how these add value compared to existing mitigation strategies (COMPET-5-2017).

The definition of space weather in U.S. National Space Weather Program Strategic plan is following: "conditions on the sun and in the solar wind, magnetosphere, ionosphere, and thermosphere that can influence the performance and reliability of space-borne and ground-based technological systems and can endanger human life or health (Inside GNSS, 2007).

Space Weather makes impact on: Earths' climate, electric power transmission, GNSS systems, HF radio communications, satellite communications, satellite drag.

Space Weather phenomena, which includes: geomagnetic storms, ionospheric scintillation, solar flares, aurora, solar radiation storm, is influenced by 11-year solar cycle. Last maximum of the solar activity was observed on May 2013. During this period the far ultraviolet portion of the solar spectrum intensifies, reaching Earths' ionosphere, making it thicker and denser.

The space weather is one of the main sources of errors experienced by GNSS systems and their users. It is one of the major sources of errors for single-frequency GNSS receivers, as well as for differential GNSS applications. The development of space technology has reached an application level, where to predict space weather becomes significant (Caunite, 2010), (SDO Mission, 2010), (ESA space weather awareness, 2017), (Schmidt, 2018).

NASA has developed a Solar Dynamics Observatory satellite to study processes on the Sun, especially during the period of solar activity.

At the Institute of Geodesy and Geoinformatics (GGI), University of Latvia, there was a research carried out (Balodis et al., 2017). For the data processing there were chosen 3 different data sets including the week of geomagnetic storm of $17^{\text {th }}-18^{\text {th }}$ of March 2015 (so called St. Patrick's Day storm), the month of June 2015 and September 2015. The five-minute resolution GNSS observation data for the 30 continuously operating GNSS reference stations covering the territory of Latvia were computed in kinematic mode by the Bernese GNSS Software V5.2, 
a scientific, high-precision, GPS/GLONASS (GNSS) data processing software package developed at the Astronomical Institute of the University of Bern. The additional service programs were developed in GGI to analyze the computed results. The results represented a reasonable contribution for recognition of space weather phenomena. The space weather phenomena are a reason for GNSS related navigation sudden errors (Cherniak et al., 2015). Studies of the space weather affected GNSS observations in year 2016 are carried out at the GGI. The overview of results will be included in current conference report.

\section{Acknowledgements}

The research was developed under the contract ERAF No.1.1.1.1/16/A/160.

\section{REFERENCES:}

1. COMPET-5-2017 - Space Weather. http://cordis.europa.eu/programme/rcn/701815_ en.html

2. Engineering solutions from the Global Navigation Satellite System community. 2007. Inside GNSS. November/ December 2007 Volume 2, Number 8; p 30-31

3. Caunite M. 2010. Ionosphere and NASA solar dynamics observatory mission. Rīgas Tehniskās Universitātes zinātniskie raksti. 11. sērija. Ģeomātika. 7. sējums. RTU izdevniecỉba, Rīga-2010. ISSN 1407-7345. 31.-34. lpp.

4. SDO Mission. 2010. https://sdo.gsfc.nasa.gov/mission/

5. ESA space weather awareness. 2017. http://swe.ssa.esa.int/

6. Schmidt M. 2018. Geodetic space weather research. http://www.ggosdays.com/en/ focus-areas/geodetic-space-weather-research/

7. Janis Balodis, Inese Varna, Diana Haritonova, Madara Normand, Gunars Silabriedis. 2017. Ground Based Kinematic GNSS Observation Results Affected by Space Weather Fluctuations in 2015; Baltic J. Modern Computing, Vol. 5 2017. No. 3, 251-268.

8. Cherniak, I., Zakharenkova, I., Redmon, R.J. (2015). Dynamics of the highlatitude ionospheric irregularities during the 17 March 2015 St. Patrick's Day storm: ground-based GPS measurements, In: Space Weather, 13 (9), 585-597, DOI:10.1002/2015SW001237. 


\title{
THE RUINS OF ANCIENT STONE STRUCTURES ON THE ISLANDS OF THE FIRST CATARACT OF NILE IN EGYPT
}

\author{
V. Seglin,š' , A. Kukela', B. Lazdiña ${ }^{2}$ \\ ${ }^{1}$ University of Latvia, Faculty of Geography and Earth Sciences \\ ${ }^{2}$ University of Latvia, Innovation Centre \\ E-mail: agnese.kukela@/u.lv
}

\begin{abstract}
In Ancient Egypt it was assumed that the Nile originates at the first cataract where it starts its flow. There are many rocky islands in that holy place, where numerous ancient signs are known, including the famous Famine Stela. It was also studied by Latvian researchers J. Kletnieks and R. Pipars. The photo archives of these studies are very little known, but these archived made it possible to notice the unusual shapes of the surrounding stone blocks. The studies carried out in the framework of this research allowed us to recognize Egyptian archaic period rock stacks and megalithic structures in nature, pointing to the need for detailed research in the future.

\section{Introduction}

Nowadays Aswan is located northward, down the Nile, from the first water springs of the river, which in many ways represents a critical point not only for the availability of the ancient Egyptian lands, but also as a very important place for exchanging and trading goods. Here, the most distant southern Nile water level and annual flood observation and forecasting point was created already during the Old Kingdom of Ancient Egypt. During that period, Aswan or Sueneta was a small village, while the city itself and its characteristic temples were located in $\mathrm{Abu}$ - a city located on Philae Island. If the temples located on Philae Island were dedicated to the most important gods who were responsible for the regular and abundant Nile water floods, in Aswan, in its turn, the only worshiped deity was the goddess of ancient obstetrics, fertility and abundance. The main concern of this deity was smooth process of birth and sufficient opening of uterus. However, outside of this region, the goddess was a regarded as a caretaker for the Nile's origins, the emergence of which, according to ancient Egyptians, takes place just on the spot of the first springs of water. This is the place where the Nile is born. It is a holy place, and the most important prayers to the gods were implored here.

On the Nile between Philae and Aswan, many rocky islands of granite and diorite are located, and for inexperienced sailor it is impossible to navigate the river safely in that section. That is why there are a lot of directions and guiding signs for boaters located here, including simple addresses and warnings, and indications for trading. However, some of these inscriptions are particularly noteworthy as they
\end{abstract}


concern the decrees issued during the reign of different kings, as well as the songs of praise (hymns) and gratitude to the gods for miracles and revelations people have experienced. However, the best known of them is the extensive inscription on the Sehel Island on a massive two-tiled cliff stone, most commonly referred to as the Famine Stela. The inscription on previously processed stone was made during the Ptolemaic dynasty, which ruled from 332-31 BC. The inscription consists of 42 columns and refers to the seven-year period of drought and famine during the reign of the $3^{\text {rd }}$ dynasty king Djoser. During these years the Nile has not flooded the farm lands and there are descriptions how the Egyptian people are suffering. King Djoser asks the priest staff under the supervision of high lector priest Imhotep for help.

The Famine Stela was studied several times (Lichtheim, 2006). More extensive studies were carried out by Dr.eng. Janis Kletnieks and film operator Romuands Pipars. These particular materials served as a basis for the hypothesis verified in the current study.

\section{Study}

The study was carried out during 2001-2013 beginning with the detailed studies of the available literature, aerial and aerospace photographs, photo images of Sehel Island cliffs documented by various authors, collection of photo and video materials of J.Kletnieks and R.Pipars (photo and video material archive of "Gilde" film studio, Latvia), and further performing studies on site. The observations and measurements were not made instrumentally because the necessary permission was not received.

\section{Results}

The materials obtained demonstrate that significant amount of rocks and individual stones from the island have been moved and mostly for construction purposes. Most likely, this relates to the period before high value granite and diorite deposits were discovered near ancient Sueneta during the Old Kingdom. It is a well-known building material that was purposefully used before the Roman times in most Ancient Egyptian large constructions and monuments.

The ancient arrays of granite, gneiss and diorite here at the Nile's first cataract are naturally cracked and weathered, Nile was breaking through them, leaving hundreds of islands behind. All around weathered rock massifs are scattered and their exposed part is represented as large blocks, boulders and large debris, often quite suitable for direct application in construction. However, their dominant size is measurable in meters, their mass exceeds tens of tons, and the quality of the material itself is quite different from its weathering intensity. It is easy to see that the blocks and pieces of stone enclosed here on some of the Nile Islands are intact, but on the other islands - they are substantially shifted, broken, and elsewhere, simply removed. It is typical for the largest islands such as Sehel, Saluga, 
Ambunarti, Elephantine, and less typical for Agilkia, Bigeh and Aba. Many islands are periodically or permanently inhabited, and therefore, the natural geological structure of the island has been modified to the advantage of economic needs.

The well-known Famine Stela, bearing the inscription on an imposing size stone is just one of the several thousand inscriptions and images known here on the Sehel Island (Fig.1). However, in the sense of historical value this inscription of the Famine Stela is the most significant. The inscriptions on stones and cliffs were created during more than two thousand years long period, but to this day mostly the inscriptions written during the Ancient Egyptian era remains. Most of these inscriptions were put by deliberately choosing the most appropriate stone surface and further removing weather layer of the rock and smoothing the surface with bronze tools.
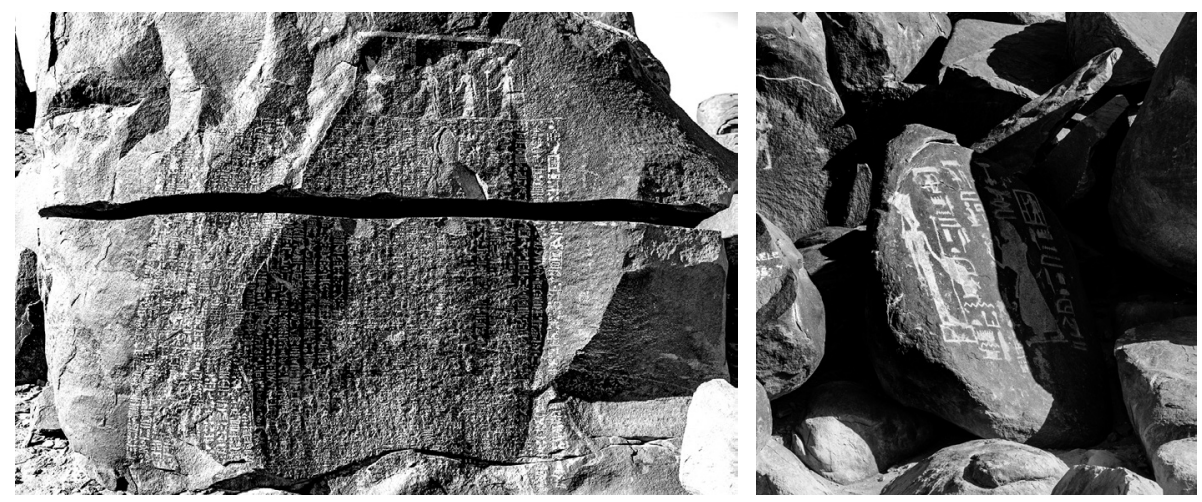

Fig. 1. Stone monuments of Sehel Island. The Famine Stela (left) and characteristic water drop shape of the stone block with later inscription on it (right).

However, besides these historic monuments, large-sized stones and separate blocks are also present. These stones were simply processed using stone tools, they were given a new shape, but the surface is only roughly cut without removing the natural weathering crust from it. Typically, the treated surfaces are also heavily weathered and indicate the age of this stone surface treatment. Yet, the thickness of the weathered crust and the natural damage to the surface on these stones are significantly more intense than the surfaces of stones with ancient inscriptions. Indirectly, these are indications that this kind of shaping of stones and processing of surfaces have been made much earlier than the oldest inscriptions - much earlier than the Old Kingdom of Ancient Egypt. There are not many stones of that kind, but they form clusters and groups, that are still preserved just in some places. It is difficult to distinguish them on site from natural formations and from stacks of rocks transformed and newly constructed during the last centuries. Most of them refer to various planned and unrealized construction projects. At the same time, 
there are remains of artificially constructed structures and ruins on the islands, which are still recognizable even in publicly available Google satellite imagery and also in nature (Fig. 2).

The aforementioned artificial rock stacks are not easily recognizable in their original shape, but nowadays on the plans they are seen as oval or deformed rings, often a set of several structures where ovals have been supplemented with linear stacks. From many of them now only a small part remains, and it is easy to employ imagination and subjectivity in the interpretation of their initial forms and shapes. A significant limitation is also the difficulty to observe these forms in nature, as it is not possible to find a reliable point of observation or it is not available for various reasons. However, extremely simple treatment of the stone surfaces with stone tools, stones shaped by humans and developed crust of weathering is clearly visible on site.
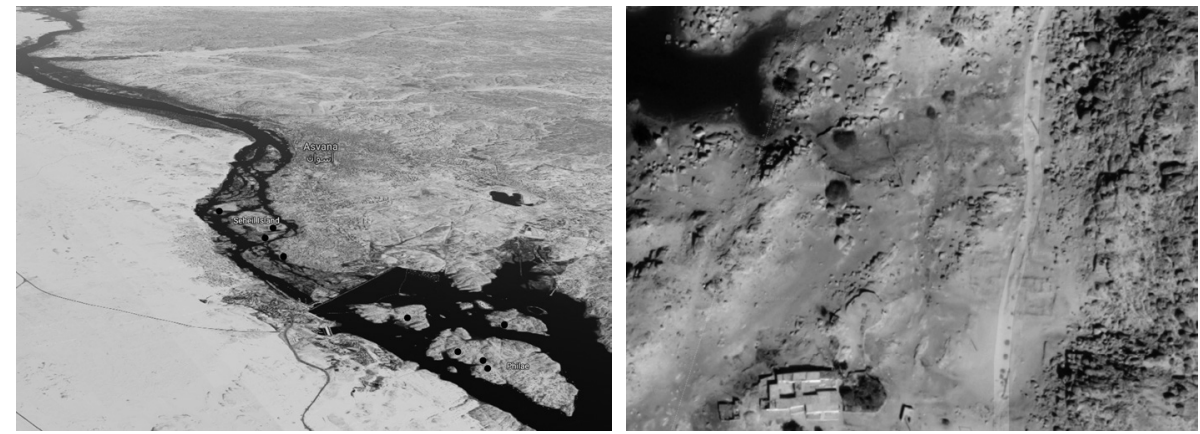

Fig. 2. Stone stack structures on the Nile Islands around Aswan recognizable on site: better recognizable structures (marked with the dots on the left) and an example of the rock stacks scattered on Philae Island on Google's satellite image (right)

\section{Conclusions}

Our studies indicate that there is a significant amount of simply treated stones in the Nile's first cataract islands near modern Aswan. Their shape and treatment was done using very primitive tools. The development of the weathering crust indicates that such treatment was made much earlier than the inscriptions found here, and this indicates the creation of the oldest treated stones here in archaic times of Ancient Egypt, which relates to the end of the Neolithic period. Stones and blocks that were simply treated are often arranged in artificial constructions these are stacks of stone blocks, the shape of which is only partially preserved. However, the lines, ovals and circles created are characteristic for many megalithic structures not only in Europe, but also in many parts of the world (Seglins, 2012). On the islands of the Nile near Aswan there are located many objects and sites that 
most likely to be explored and studied in details in the future. Such studies would significantly expand the prehistoric period of Ancient Egypt.

Acknowledgements

The research was supported by Latvian National Research Program "ResProd" No. 2014.104/VPP-6/4.1 project "GEO".

\section{REFERENCES}

1. Lichtheim, M. (2006). Ancient Egyptian Literature: The Late Period. University of California Press, ISBN 978-0-520-24844-1 (vol.3); pp. 94-100.

2. Seglins, V. (2012). Megaliths in the World and Latvia, Riga, LU Akadēmiskais apgāds, ISBN 978-9984-45-554-9; pp. 417-420. 


\title{
USE OF UNMANNED AERIAL VEHICLE (UAV) FOR COASTAL ZONE MANAGEMENT: A CASE STUDY OF TERKOSERKOS
}

\author{
D. Z. Seker \\ Istanbul Technical University, Department of Geomatic Engineering, Istanbul,Turkey \\ E-mail: seker@itu.edu.tr
}

Due to the coastal zone area is one the most valuable asset for marine and fish, wildlife and human lives, monitoring them is essential for environmental protection and decision making. Shorelines are one of the essential coastal features and shoreline extraction is a fundamental step to determine the dynamics of shorelines to prevent natural and human-based influences and to conserve natural habitat. Coastal areas are also prone to environmental hazards such as erosion and sedimentation processes that may cause loss of coastal land and damage infrastructures and buildings. Damages are mostly occurring as loss of life, houses, transport, land and fishery equipment. Due to coastal topography is fundamental variable for coastal zone management, mapping of these regions is becoming more important. Map is not only whole or part of an area, they are also used to describe spatial relationships of specific features that the map aims to represent.

Unmanned aerial vehicles are a highly preferred platform in recent years for obtaining spatial data required for many applications. Coastal areas are of interest to a large number of engineering disciplines and also among the studies that can be done with unmanned aerial vehicles due to the dynamic structures they have, and good coverage of the study area provided by high-resolution photographs obtained in a short period of time. Turkey which is a country shaped peninsula and approximately three-quarters surrounded by the sea has a great potential for the use of these devices along coast lines.

Recent developments in Unmanned Aerial Vehicle Systems give a big opportunity for shoreline mapping due to their low-cost, high resolution and accurate data collection performance. In this study, $3,5 \mathrm{~km}$ shoreline of IstanbulTerkos Lake which lie on the Black Sea coastline has been chosen as the study area within the scope of TUBITAK Project (Project No: 115Y718) entitled as "Integration of Unmanned Aerial Vehicles for Sustainable Coastal Zone Monitoring Model - Three-Dimensional Automatic Coastline Extraction and Analysis: Istanbul-Terkos Example."

The advantages in developing the technology of UAV for low altitude photogrammetric mapping are to perform aerial photography at cloudy day, to get full image of object from the top, and to supply a cheap and easy system for high frequency needs of aerial photogrammetric survey. UAV system is not limited by human on aircraft for data collection in dangerous of hazardous environment without risk of pilot. 
To efficiently manage the coastal zone, frequent surveys are required to detect and quantify associated morphological changes. In this study, mapping and collecting related data about the coastal morphology are collected by means of UAV based photographs to identify, quantify and understand the coastal area of the study region. Additionally, geographic extent of the study region was defined, possible relationships between coastal zones and other related factors were defined for possible planning and management operations which are very important for coastal monitoring programs. 


\title{
RESEARCH ACTIVITIES AT THE INSTITUTE OF GEODESY AND GEOINFORMATICS
}

\author{
G. Silabriedis \\ University of Latvia, Institute of Geodesy and Geoinformatics \\ E-mail: gunars.silabriedis@lu.lv
}

The research activities at the Institute of Geodesy and Geoinformatics (GGI) are strongly related to the execution of current projects. The ideas are developed continuously for eventual new project proposals. Most important for the personnel of GGI is the European Regional Development Fund project "Development of the high accuracy gravity field model for Latvia including sea territory" 1.1.1.1/16/A/160

The application of high precision Earth gravity model is important for many economic branches - geology, application of space related GNSS methods in geodesy and land surveying, civil engineering, maritime, etc. For high precision gravity field model, the data of different sources were collected: Global Earth gravitational field models, ground based gravimetric measurements, vertical deflection measurements applied by zenith camera, highest order levelling point data combined with GNSS applied height measurements above the Earth rotational ellipsoid, as well as the gravity measurements over the Latvian territory and Baltic sea territorial waters. The main attention in year 2017 was paid to performance of the field measurements: GNSS related ellipsoidal height measurements and vertical deflection measurements by using digital zenith camera. The application of digital zenith camera was rather complicated because of both weather conditions and very short nights in summer time. The clear night sky is essential for successful observation. The observation session at one site takes at about 1 hour. The distance between two neighboring points was not less than $20 \mathrm{~km}$. In spite of this the successful Zenith camera observations at 62 sites were completed. Zenith camera construction and control software now seems to be finalized and performing up to expectations.

GNSS 4 hour long static observations were performed at 250 first order levelling point sites.

The DFHRS v.4.3 software was developed and successfully applied by Katerina Morozova under supervision of professor Reiner Jaeger (Karlsruhe University of Applied sciences, Germany) for quasi-geoid determination by using zenith camera observation results.

Additionally, the normal heights of Latvian first and second order levelling data and the gravity measurement results were kindly delivered by Latvian Geospatial Information agency (LGIA). 
The active research work was performed by the staff of GGI. The results were reported in scientific meetings, conference proceedings and published in Scopus and/or Web of science indexed papers. List of these data presented below in References.

GGI activities on the LatPOS and EUPOS-Riga GNSS observation reduction is continued already $11^{\text {th }}$ year. The SINEX results are forwarded to EUPOS ${ }^{\circ}$ Combination Centre (ECC). The results are included in EPOS (European Plate Observation System) project and in EPN Densification project (Kenyeres et al. 2016). The GGI data base Latpos and EUPOS ${ }^{\circ}$-Riga GNSS observation reduction continuously updated. On this basis the space weather studies in GGI are continued.

The satellite laser ranging system was continuously developed. Installation and adjustment of multi-purpose optical tracking instrument on the roof of former library building at Lielvārdes street 24 was carried on. Tracking hardware and optical systems were installed and are in the process of tests and adjustment. Control computer network was set up and control software installed. Measurements for mount coordinate system and mount error model parameter determination are commenced. Transmitting pulse laser was installed and adjusted. Meteostation and GNSS receiver for time synchronization were installed. An initial GNSS measurement session for accurate coordinate determination of instrument site was carried out. An optoelectronic device for reflected optical signal detecting and processing was designed. The activity will proceed with more measurements for mount error model determination, adjustment of transmitting and receiving hardware and test observations.

Several IT solutions were developed in GGI, which can be used in different spheres of the national economy. For example, an adaptive software for video data processing and automated analysis are offered for the technology transfer in the forestry sector. Within the framework of an effective cooperation project with JSC "Latvia's State Forests", a methodology and IT solution for the automated survey of timber assortment volume for forestry needs is being developed.

Copernicus is the European Commission space program for Earth observation and remote sensing. Senior researcher Ingus Mitrofanovs is the delegate of Latvia on Copernicus User Forum. Under his supervising the project proposals for assigning the labels of Copernicus Relays and Copernicus Academy for the University of Latvia were submitted to the European Commission. He also manages the participation of University of Latvia in the consortium within the Horizon2020 project for Copernicus User Uptake. These activities are being implemented under the contracts No. Y5-227850-PK-N-015 and No. S193-ESS198F-ZF-N-290. 


\section{Acknowledgements}

The research was developed under the contract No. S193-ESS198F-ZF-N-290

\section{REFERENCES:}

1. Katerina Morozova, Ansis Zarins, Janis Balodis, Augusts Rubans, Reiner Jaeger. Digital zenith camera's results and its use in dfhrs v.4.3 software for quasi-geoid determination. Proceedings, 2017 Baltic Geodetic Congress (Geomatics). Gdansk University of Technology, 22-25 June 2017, Poland. 978-1-5090-2421-6/\$31.00 (C2016 IEEE p. 174-178. DOI 10.1109/BGC.Geomatics.2017.74

2. Balodis J., HaritonovaD., Normand M., Silabriedis G. Ground based kinematic GNSS contribution dealing with space weather observations. Abstract Book. Fourth SWARM Science Meeting and Geodetic Missions Workshop. Banff, Alberta, Canada. 20-24 March 2017. P. 72 http://esaconferencebureau.com/docs/defaultsource/17c04-docs/abstract-book-nbsp-.pdf?sfvrsn=0

3. Balodis J., Janpaule I., Normand M., Jumare I. Silabriedis G. 10-year Time Series of GNSS Daily Solutions, Geomagnetic Storms and Biggest Earthquakes. Abstract Book. Fourth SWARM Science Meeting and Geodetic Missions Workshop. Banff, Alberta, Canada. 20-24 March 2017. P. 26. http://esaconferencebureau.com/docs/ default-source/17c04-docs/abstract-book-nbsp-.pdf?sfvrsn=0

4. Inese Varna, Janis Balodis, Diana Haritonova. Geomagnetic Storms, Earthquakes and their Influence on GNSS Coordinate Time Series. Proceedings ITISE 2017. Granada, 18-20 September 2017. ISBN: 978-84-17293-01-7. P 122-128.

5. J Balodis, K Morozova, M Reiniks and M Normand. Normal heights for GNSS reference station antennas. IOP Conf.Series: Materials Science and Engineering 251 (2017) 012063 doi:10.1088/1757-899X/251/1/012063. P. 1-6

6. iopscience.iop.org/article/10.1088/1757-899X/251/1/012063/pdf

7. K Morozova, R Jaeger, J Balodis and J Kaminskis. Software development and its description for Geoid determination based on Spherical-Cap-Harmonics Modelling using digital-zenith camera and gravimetric measurements hybrid data. IOP Conf. Series: Materials Science and Engineering 251 (2017) 012065 doi:10.1088/1757899X/251/1/012065. P. 1-9

8. Janis BALODIS, Inese VARNA, Diana HARITONOVA, Madara NORMAND, Gunars SILABRIEDIS. Ground Based Kinematic GNSS Observation Results Affected by Space Weather Fluctuations in 2015. Baltic Journal of Modern Computing. University of Latvia. Vol. 5 (2017) No. 3. 251-268. ISSN 2255-8950 (online). ISSN 2255-8942 (Print). http://www.bjmc.lu.lv/ http://www.bjmc.lu.lv/ fileadmin/user_upload/lu_portal/projekti/bjmc/BJMC_Cover_400.jpg

9. Klūga, Jānis. Experimental results of attitude determination with high precision GNSS receivers / Janis Kluga, Ansis Kluga, Ingus Mitrofanovs // Advances in Wireless and Optical Communications (RTUWO 2016); Riga, Latvia, November 3-4, 2016: Proceedings [Riga, 2016] (2017), Article number: 7821861, p. 85-88. DOI: 10.1109/RTUWO.2016.7821861., URL: http://ieeexplore.ieee.org/ document/7821861/ ISBN 9781509015351.

10. Marita Cekule, Irina Baltmane. The potential urban open spaces identification methodology for the strategic planning in neighborhoods. $17^{\text {th }}$ International Multidisciplinary Scientific GeoConference Surveying Geology and Mining 
Ecology Management, SGEM2017, 29 June - 5 July, Albena, Bulgaria: Conference Proceedings Albena, 2017 Vol. 17, N 23 (2017), p. 743-752. DOI: 10.5593/ sgem2017/23/S11.093, ISSN 1314-2704.

11. Kaspars Chabs, Marita Cekule. Video - Based human behavior interpretation and modelling with the statbox concept. $17^{\text {th }}$ International Multidisciplinary Scientific GeoConference Surveying Geology and Mining Ecology Management, SGEM2017, 29 June - 5 July, Albena, Bulgaria: Conference Proceedings Albena, 2017. Vol. 17, N 21 (2017), p.1127-1134. 


\title{
SPACE WEATHER AND EARTHQUAKE INFLUANCE ON GNSS SOLUTIONS
}

\author{
I. Varna, J. Balodis \\ University of Latvia, Institute of Geodesy and Geoinformatics \\ E-mail: inese.janpaule@/u.Iv
}

Since year 2007 the daily coordinates of both LATPOS and EUPOS-Riga continuously operating GNSS (Global Navigation Satellite Systems) RTK (Real Time Kinematic) reference network stations (CORS) are computed and all data are stored at the Institute of Geodesy and Geoinformatics. These data represents long term positioning stability of LATPOS and EUPOS-Riga stations. Additionally, some detailed studies have been realized by performing the five-minute kinematic solutions for several time periods with high geomagnetic activity: the week of St. Patrick's Day storm in March 2015, June and September 2015, January, October and December 2016 (Balodis et al. 2017).

On September 6, 2017, X9.3 X-ray solar flare erupted from the Sun, it was the most powerful X-ray flare of the current solar cycle. It produced a severe G4 geomagnetic storm when it reached Earth on the evening of 7 September (SpaceWeatherLive). To analyse the influence of this geomagnetic storm, the fiveminute kinematic solution was performed for September 2017.

The Baltic region has a relatively small seismic activity; however, since installation of LATPOS and EUPOS-Riga in 2007, some earthquake events have been detected in Baltic region. Residents of Riga felt an earthquake in November 22,2010 . Based on survey data and eyewitness reports, specialists concluded that tectonic shocks were caused by movement in Olaine-Inčukalns and Bergu tectonic zone (Nikulins 2017a). On September 15, 2014, a 4.7 magnitude earthquake took place in South of Sweden, $43 \mathrm{~km}$ North-East of Älvdalen (European-Mediterranean Seismological Centre). On November 12, 2016, a 2.5 magnitude earthquake took place in the Lake Võrtsjärv area in Estonia (Nikuḷins 2017b).

Because of coordinate changes at the end of July 2015, a special interest caused earthquakes in Sweden on July 29, 2015, magnitude $M=3.4$, and on July 30, 2015, magnitude $M=4.1$, depth $15 \mathrm{~km}$. Velocity trends were broken sharply after the earthquake event in Sweden (Varna et al. 2017).

Discrepancies in GNSS CORS positions are analyzed in order to discover the influence of above mentioned earthquakes.

Acknowledgement

The research was developed under the contract ERDF No.1.1.1.1/16/A/160 


\section{REFERENCES:}

1. Balodis J., Varna I., Haritonova D., Normand M., Silabriedis G. Ground Based Kinematic GNSS Observation Results Affected by Space Weather Fluctuations in 2015. Baltic J. Modern Computing, Vol. 5 (2017), No. 3, 251-268.

2. N̦ikuḷins V. (a) Olaines - Inčukalna - Berǵu lūzumu zonas seismotektoniskās aktivitātes pazīmes. Latvijas Universitātes 75 . zinātniskā konference. Lietišḳi geolog̣iskie pētī jumi. Tēžu krājums. Rīga, Latvijas Universitāte, 26-28 (2017).

3. N̦ikulins V. (b) Estonian earthquake 12 November 2016 and its seismotectonic position. Latvijas Universitātes 75. zinātniskā konference. Lietišḳi geologiskie pètī jumi. Tēžu krājums. Rīga, Latvijas Universitāte, 29-31 (2017).

4. Varna I., Balodis J., Haritonova D. Geomagnetic Storms, Earthquakes and their Influence on GNSS Coordinate Time Series. Proceedings of ITISE 2017 - International Work-Conference on Time Series Analysis, Granada, September 18-20, 2017. Volume 1, 122-128.

5. European-Mediterranean Seismological Centre (available at: https://www.emsc-csem. org/Earthquake/earthquake.php?id=399965).

6. SpaceWeatherLive Real-time auroral and solar activity, Top 50 geomagnetic storms of 2017 (available at: https://www.spaceweatherlive.com/en/auroral-activity/top-50geomagnetic-storms/year/2017). 


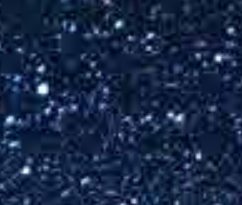

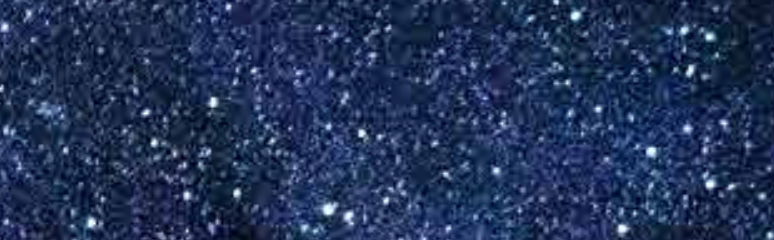
$+$ 